\title{
IN SEARCH OF SUBSTITUTION BETWEEN FOREIGN PRODUCTION AND EXPORTS
}

\author{
Bruce A. Blonigen
}

Working Paper 7154

http://www.nber.org/papers/w7154

\author{
NATIONAL BUREAU OF ECONOMIC RESEARCH \\ 1050 Massachusetts Avenue \\ Cambridge, MA 02138 \\ June 1999
}

I thank Stephen Haynes, Keith Head, William Hutchinson, Robert Lipsey, Raymond Mikesell, Matthew Slaughter, Wesley Wilson, anonymous referees and participants of the fourth annual Empirical Investigations in International Trade Conference at Purdue University and the 1998 NBER Summer Institute for helpful comments. All remaining errors or omissions are the responsibility of the author. All opinions expressed are those of the authors and not those of the National Bureau of Economic Research.

(C) 1999 by Bruce A. Blonigen. All rights reserved. Short sections of text, not to exceed two paragraphs, may be quoted without explicit permission provided that full credit, including $(\mathrm{C}$ notice, is given to the source. 
In Search of Substitution Between Foreign

Production and Exports

Bruce A. Blonigen

NBER Working Paper No. 7154

June 1999

JEL No. F21, F23

\begin{abstract}
Are foreign production and exports substitutes or complements? The continuing globalization of production makes the question of the relationship between trade and foreign direct investment ever more important. Standard theory of the multinational corporation (MNC) assumes substitution, while previous empirical work examining the relationship has generally found strong evidence of complementarity. This study examines product-level data, which more closely fits the assumption of a single-product firm often used in MNC theory, and finds substantial evidence for both a substitution and a complementarity effect between affiliate production and exports with Japanese automobile parts for the U.S. market. I also test for and find evidence of substitution using product-level data on a set of Japanese-produced final consumer goods. Thus, product-level data allows one to separately identify substitution from complementarity effects (here from vertical production relationships), rather than try to infer them from estimates using more aggregate data. In this sense, the paper highlights the importance of matching the level of data aggregation with the hypotheses being tested. This is particularly true at a time when there is an increasing proliferation of available microeconomic data in the field of international economics.
\end{abstract}

Bruce A. Blonigen

Department of Economics

1285 University of Oregon

Eugene, OR 94703-1285

and NBER

bruceb@oregon.uoregon.edu 


\section{Introduction}

The continuing globalization of production makes the question of the relationship between trade and foreign direct investment ever more important. An important question that has arisen in both the theoretical and empirical literature is the extent to which exports and foreign production are substitutes or complements. More precisely, to what extent do production and affiliate sales in a foreign market replace or help increase exports to the same market? ${ }^{1}$ While there are theoretical reasons to suggest both substitution and complementarity effects, surprisingly, empirical work in this area almost invariably shows a net complementarity relationship between exports and foreign production (or foreign affiliate sales) across a wide variety of data sets. Lipsey and Weiss (1981), Graham (forthcoming), and Clausing (forthcoming) are examples of studies that find affiliate sales positively correlated with exports at the aggregate country or industry level. Other studies have examined the relationship between affiliate sales and exports using firm-level data, including Swedenborg (1979; forthcoming), Lipsey and Weiss (1984), Blömstrom et al. (1988), Head and Ries (1997), and Belderbos and Sleuwaegen (1998). One might expect that the more disaggregated nature of the firm-level data would be more likely to yield net substitution, yet almost all these studies find net complementarity as well. Thus, we are left with apparent incongruities between theory and empirical work.

This paper attempts to shed new light on the empirical relevance of substitution and complementarity effects between exports and foreign affiliate sales by examining product-level

${ }^{1}$ The "substitution/complementarity" terminology may be confusing because the question is not concerning how a quantity changes with respect to changes in a price in this context, as in a typical demand analysis. Rather, the question addresses how changes in one quantity affect another quantity. While the terminology may be confusing, I use the "substitution/ complementarity" terminology in this paper because it has become standard in the literature. 
data. The advantage of using highly disaggregated product-level data is the ability to test for a substitution effect separately from complementarity effects, such as those arising from vertical linkages. Because of availability, I use data on Japanese production in and exports to the United States for two types of products. ${ }^{2}$ First, I examine data on automobile parts, which obviously have a strong vertical relationship with automobile production. Production of Japanese automobiles (the input-using industry) in the United States should increase Japanese exports of automobile parts to the United States (a complementarity effect), while location of Japanese automobile parts production in the United States should decrease Japanese exports of automobile parts (substitution effect). Simple plots of Japanese exports and Japanese production in the United States for ten specific automobile parts products generally show large substitution effects, even without controlling for the potential increased demand for these products due to increased Japanese production of automobiles in the United States. Thus, product-level data shows strong net substitution, unlike previous studies using more aggregated data. I then test more formally for a substitution effect (from increased U.S. automobile parts production by Japanese firms) and a complementarity effect (from increased U.S. automobile production by Japanese firms) on Japanese exports of these automobile parts products, controlling for other factors. The regression results indicate substantial evidence for both effects.

While examination of automobile parts is interesting because of its vertical relationship with automobile production, it may be difficult to generalize the substitution effect results

2 Japanese data are used primarily because of a unique data set on Japanese production in the United States published by the Japan Economic Institute which is detailed enough to list specific products produced at the plant level, rather than a more aggregated industry designation (such as 4-digit Standard Industrial Classification), as is usually the case. Below I detail the data constraints that largely dictated the sample of products I was able to examine. 
displayed by Japanese automobile parts in the United States because of U.S. pressure for transplanted Japanese automobile firms to source more inputs domestically (see Swenson [1997]) In other words, political influences may be driving the large net substitution effects displayed by these products. This may be the case for any product subject to some form of protectionism. Therefore, I next examine substitution effects between Japanese exports and Japanese production in the United States using product-level data on eleven final consumer products which were not subject to such U.S. government scrutiny over my sample period. The evidence from simple plots and more formal statistical analysis strongly suggests substitution of local production for exports with most of these consumer products as well. In fact, both sets of results (automobile parts and consumer products) are surprisingly strong given the limited number of observations I am able to employ. In addition, the evidence suggests that when firms locate production abroad, the substitution effects are large one-time changes, not gradual steps over time.

\section{Previous literature}

Theoretical models used to analyze a multinational corporation's (MNC's) decision to sell to a foreign market often assume the firm chooses between exporting or foreign production in the host country. In fact, one of the main research questions in this literature is why a MNC chooses one mode of servicing the foreign market versus the other. ${ }^{3}$ Buckley and Casson (1981) suggest

${ }^{3}$ In a standard Heckscher-Ohlin general equilibrium model with factor mobility, the classic paper by Mundell (1957) showed that factor flows (e.g., capital in the form of foreign direct investment) may substitute for trade flows in these general equilibrium models as well. However, Markusen (1983) and Wong (1986) show that there are numerous theoretical reasons for possible complementarity when standard Heckscher-Ohlin assumptions are relaxed. This paper will focus more on models of MNCs mentioned in the text to motivate the empirical framework, though the empirical results of this paper may have implications for both types of models. 
that while exports naturally incur higher costs per unit than foreign production because of greater transportation costs and possible tariffs, foreign production involves a higher fixed cost of operation (e.g., building a new plant). This implies that for lower levels of sales, firms will export to avoid the higher fixed costs associated with foreign production, whereas they will switch to foreign production for higher level of sales. Markusen $(1984 ; 1995)$ suggests that firm-specific assets may lead a firm to locate production abroad rather than export. Firm-specific assets have a public goods aspect to them in the sense that they can be used across multiple plants for a single firm-level investment. Thus, it may make sense for the firm to locate production in a variety of markets rather than have one production plant that exports to the many markets. Finally, the theory of internalization suggests that foreign direct investment (FDI) substitutes for exports when there are sufficient costs to external transactions such as exporting or licensing. ${ }^{4}$ Thus, the substitution effect plays a prominent role in theory.

At the same time, there are theoretical channels by which complementarity may occur between exports and foreign production. Lipsey and Weiss (1984) and Rugman (1990) argue that a firm's production presence in a foreign market with one product may increase total demand for all of its products through a number of channels including 1) provision of important sales and after-sale services, 2) commitment-to-market effects on consumers, and 3) more efficient and quicker deliveries and distribution. In this way, foreign production and sales of one good may create what Brainard $(1993 ; 1997)$ terms "proximity advantages" by promoting export sales of

${ }^{4}$ Internalization has its roots in Williamson's (1975) transactions cost work and has become familiar to international trade economists through Dunning's (1981) ownership-locationinternalization (OLI) framework. Markusen (1995) has a nice discussion of the OLI framework as it applies to models that use firm-specific assets as a motivation for MNCs. 
goods produced by the firm in its home country. A vertical production relationship is another way that complementarity may occur. Investment by a manufacturer may increase exports of inputs to the host market. Foreign sourcing of parts by transplant firms and its effect on the U.S. trade deficit has caused concern in recent years. For example, Swenson (1997) finds that Japanese transplanted automakers import a large amount of parts from Japan and are much less willing to substitute between U.S. and imported inputs. Thus, there are a number of reasons why foreign production may complement exports.

As mentioned in the introduction, empirical studies almost invariably find net complementarity. This has been true of not only country- and industry-level studies, but also firm-level studies. The strength of the complementarity effect even at less-aggregated levels of data, such as firm-level, is surprising at first glance. However, even firm-level data does not allow one to separately identify a substitution effect to the extent that the firm is multiproduct, which is quite likely given that the companies examined are large MNCs. The multi-product nature of the firm means that there may be demand complementarities across a firm's products and/or there may be vertical production relationships across the firm's products. Additionally, even firm-level data makes it more difficult to disentangle what drives the complementarity. Is it demand complementarities or vertical relationships? ${ }^{5}$

There have been a number of responses in the literature to these empirical findings. First,

${ }^{5}$ For example, Lipsey and Weiss (1981) suggest that their finding of a positive correlation at the industry level shows that manufacturing presence in another country "tend s to promote" the firm's exports to that country. This is apparently a demand complementarity argument, yet one industry for which Lipsey and Weiss (1981) find a complementary relationship is the industry classification "automobiles and trucks." This industry comprises production of both finished autos, as well as automobile parts, which suggests complementarity may stem from a vertical relationship. 
a number of studies have examined whether endogeneity bias is driving the strong complementarity results. Grubert and Mutti (1991) and Graham (forthcoming) try to control for endogeneity bias when estimating the relationship between affiliate sales and trade using countrylevel data, while Head and Ries (1997) and Swedenborg (forthcoming) control for endogeneity using samples of Japanese and Swedish firms, respectively. Graham, Head and Ries, and Swedenborg generally still find net complementarity, while Grubert and Mutti find an insignificant relationship between affiliate sales and exports after instrumenting for affiliate sales.

Second, a number of studies have been able to find evidence for vertical relationships leading to complementarity with firm-level data. ${ }^{6}$ Lipsey and Weiss (1984) use information on intermediate versus finished products within the firms in their sample. They find a strong complementary relationship with respect to affiliate production and exports of intermediate goods as one would expect, but no evidence for either complementarity or substitution with respect to finished goods affiliate production and finished goods exports. Yamawaki (1991) also uses firmlevel data to look at another type of vertical relationship: the effect of Japanese FDI in wholesale distribution in the United States on Japanese exports of goods to the United States for distribution. As expected, he finds a strong complementary relationship. Head and Ries (1997) are able to identify "vertical leaders" in their data -- Japanese firms that are known to source a higher share of intermediate inputs from other firms. Thus, one would expect the complementarities from vertical production to be less prevalent for these firms. Their results confirm this and, in fact, they find some evidence for a net substitution effect for vertical leader

\footnotetext{
${ }^{6}$ A recent paper by Swenson (1998) uses industry-level data to show that less substantial complementarity and even substitution effects are revealed as one moves from more-aggregated industry FDI data to less-aggregated data.
} 
firms in their sample. In contrast, Belderbos and Sleuwaegen (1998) find evidence of substitution between foreign production and exports at the firm level by focusing on firms facing actual or threatened import protection by the destination market. They argue that one should expect a large substitution effect in these circumstances since the firms facing heightened protection are likely to substitute foreign production for exports to avoid the protection. They find evidence of substitution of local production for exports with Japanese electronic firms in the European Community (EC) during the late 1980s, a period characterized by rising EC protection against these firms.

This paper's contribution is to go one step further in the level of disaggregation to analyze product-level data. This step is taken not because it can be done, but because it makes sense. As will be shown below, there are a number of advantages to this level of disaggregation. First, it allows one to naturally model and test in the same equation a complementarity effect from vertical production linkages separately from the substitution effect of affiliate production for exports. In this sense, the empirical model is more closely linked to the theory of a single-product firm-level decision. In addition, focus on a single product also means that demand complementarities across products are not masked by the data. One potential disadvantage is data availability. ${ }^{7}$ However, the recent National Bureau of Economic Research (NBER) dat abase on U.S. imports (see Feenstra [1996]) and other recent sources of data on Japanese investment in the United States

${ }^{7}$ A second potential disadvantage is that product-level data may be capturing behavior across multiple firms. An ideal data set would have product-level data by firm. If firms are pursuing different strategies to serve a market (exports versus local production) for a particular product over a given time period, the substitution and complementarity effects occurring at the product-level within each firm may be obscured. Unfortunately, I do not have product-level export data by firm. 
have now made this product-level analysis possible. In the end, substitution and complementarity effects are easily identified with the product-level data I use, which stands in contrast to previous studies using more aggregated data. Additionally, I find that substitution effects are substantial and generally occur in large one-time changes for the products I investigate.

\section{Empirical Analyses}

This section examines two complementary sets of product-level empirical analyses. In section 3.1, I analyze whether Japanese production of automobiles and automobile parts in the United States was complementary toward and/or a substitute for Japanese exports of these automobile parts to the United States during the late 1970s through the early 1990 s. The vertical production linkage between automobiles and automobile parts is of interest because theory suggests there should be a complementary relationship between Japanese automobile production in the United States and Japanese exports of automobile parts. At the same time, there should be a substitute relationship between Japanese production of automobile parts in the United States and Japanese exports of those same products to the United States.

In section 3.2, I examine a separate set of consumer products exported from Japan and produced in the United States by Japanese affiliates. This is done out of a potential criticism that the automobile parts regressions (and particularly the substitution effects I find) are driven by the Japanese-U.S. automobile voluntary export restraints (VERs) and the politically-motivated push for high local domestic content in this trade-sensitive industry. Thus, the consumer products analysis provides some evidence whether substitution effects are significant for products besides those that are subject to substantial trade protection. 


\subsection{Japanese automobile parts and the U. S. market}

I analyze product-level data on a specific group of Japanese automobile products in two ways. First, I look at simple plots of exports and U.S. production of these products over the period of my sample, 1978-91. For most of the automobile parts products, the graphs show strong evidence for a substitution effect between Japanese exports and Japanese production of the product in the United States, despite substantial increases in Japanese-owned U.S. production of the downstream product, automobiles. Simple plots do not control for a variety of other forces that may be factors during this period, including changes in relative prices of inputs and exchange rates, so I then run seemingly-unrelated regressions (SUR) for the set of products based on a model of U.S. demand for imported Japanese auto parts. Controlling for relative prices (and implicitly exchange rate changes), the results show strong evidence for the substitution effect exhibited by the plots, as well as the complementary effect between Japanese exports of automobile parts to the United States and Japanese production of automobiles in the United States. These simple analyses are necessary due to data limitations involved with using available product-level data, but the results are consistent and strong across these two approaches.

\section{I.1. Descriptive analysis}

The 1980s were an interesting time for the Japanese automobile industry and the U.S market. To understand what occurred with Japanese automobile parts, it is informative to briefly look at the downstream automobile industry. In 1981, Japanese automakers faced a voluntary export restriction (VER) that was in effect until the mid-1990s. As shown in figure 1, U.S. 
automobile production by Japanese automakers began in 1983 and rose annually, reaching over 1 million automobiles by 1992. By 1988, Japanese exports to the United States begin declining consistently. This may be evidence of the Japanese substituting U.S. production for exports because of the VER. Alternatively, the export drop may have been purely a response to the sharp appreciation of the yen relative to the dollar, as shown in figure 1 .

Turning to automobile parts (the focus of this section's analysis), figure 2 shows Japanese automobile parts exports (Standard Industrial Classification (SIC) 3714) to the United States and the exchange rate from 1978-1992. As one would expect, there appears to be a substantial increase in the trend of automobile parts exports beginning in 1983, when Japanese automobile production began in the United States. However, this high growth in exports flattens considerably beginning in 1989, perhaps due to the stabilization of U.S. production of Japanese automobiles as seen in figure 1. In fact, Japanese automobile parts exports follow Japanese production of automobiles in the United States closely, suggesting a strong complementarity effect through this vertical linkage. However, another explanation for the flattening out of exports may be the substantial FDI by Japanese automobile parts producers into the United States to substitute for exports. Table 1 shows data on Japanese investment in U.S. automobile parts production for various years from 1980-1990. Clearly, there was substantial Japanese investment that began at least as early as 1986 in U.S. automobile parts production. The last column of table 1 shows manufacturing direct investment as a reference for gauging the size of the direct investment in automobile parts production - from 1986-90, automobile parts production accounted for 12 to 21 percent of all new Japanese manufacturing investment in the United 
States. ${ }^{8}$ What is difficult to assess from the information in figure 2 and table 1 however, is why exports of automobile parts did not flatten out sooner or even begin to decrease from a substitution effect of U.S. production for exports. The substitution effect may not be appearing as strong because of the strong demand generated by the increasing automobile production. On the other hand, the plotted U.S. production numbers by Japanese producers may represent very small levels of substitution. The inability to disentangle these various effects is the crux of the data aggregation issue.

To control for the aggregation issue, I next analyze product-level data on ten specific automobile part products: 1) toughened glass for automobiles, 2) laminated safety glass for autos, 3) automotive mirrors, 4) radio-cassette players for autos, 5) radio receivers for autos, 6) engine starters, 7) engine coils, 8) door locks for autos, 9) bumpers and parts, and 10) automobile seats and parts. These products satisfy a couple of crucial criterion. First, it was possible to construct credible data on Japanese exports to the United States for these products. I use the NBER database on U.S. imports (described in Feenstra, 1996) to construct time-series data at a detailed product level. However, there was a complete change in product code classification system in the United States after 1988 from the Tariff Schedules of the United States Annotated (TSUSA) to the Harmonized Tariff System (HTS). Unfortunately, there is far from a one-to-one mapping between these two systems. Often, one TSUSA line item is distributed across numerous HTS codes (or vice versa) making it impossible to construct a credible time series record of import activity. This substantially limited which products could be analyzed. Second, to examine the

${ }^{8}$ Using the same database, Blonigen and Tomlin (1998) also provide evidence that Japanese automobile parts plants grew much more rapidly during this period than other Japanese manufacturing plants in the United States. 
effect of foreign production, it was necessary that the automobile part product eventually was produced in the United States by Japanese firms. These ten automobile part products chosen for study have direct mappings from the TSUSA to HTS system, so that a consistent time series for Japanese imported automobile parts could be constructed, and saw significant Japanese production in the United States in the 1980s. A data appendix describes construction of the database for these automobile part regressions and accompanying data difficulties.

Figures 3A through 3D present simple plots of Japanese exports and U.S. production by Japanese firms over time for the four of the ten automobile parts products that show substantial substitution effects -- laminated safety glass, radio-cassette players, bumpers, and engine starters. While I do not present similar plots of the other six products for the sake of space (available from author upon request), three others, toughened glass, radio receivers, and seats and parts, show plausible evidence of substitution as well. In many ways, these plots are surprising in light of the fact that I am obviously not controlling for the complementarity effect of increased automobile production, nor for other factors such as relative input price and exchange rate changes.

\subsubsection{Regression analysis}

To more formally test for both substitution and complementary effects of foreign production on exports in the case of Japanese automobile parts in the United States, I assume there are two representative U.S. demanders of automobile parts: Japanese automobile subsidiaries located in the United States and U.S.-owned automobile plants located in the United 
States. ${ }^{9}$ Thus, derived demand for Japanese-produced automobile parts will be a function of automobile production by each type of producer, the price of the automobile parts, and prices of other inputs into the production process. This can be obtained by setting up a standard cost minimization problem for each type of automobile producer, solving for demand for the automobile part input and aggregating. Thus we have the following derived demand function in the United States for Japanese produced automobile parts:

$$
X_{J}^{D}=X_{J}^{D}\left(P, Y_{J}, Y_{U}\right)
$$

where $\mathrm{P}$ is a vector of input prices, and $\mathrm{Y}_{\mathrm{J}}$ and $\mathrm{Y}_{\mathrm{U}}$ are production by Japanese-owned and U.S.owned automobile producers in the United States, respectively. Supply of Japanese-produced automobile parts comes either from Japan as exports or from local production in the United States. I assume these parts are identical across the two locations and necessarily sell for the same price. If I assume that the local production facilities always operate at capacity ${ }^{10}$, then I can express net export demand as:

$$
X_{\text {JIMP }}^{D}=X_{J}^{D}\left(P, Y_{J}, Y_{U}\right)-X_{J L P}
$$

where $X_{\mathrm{ILP}}$ is the amount of local production supplied by the market. Equation (2) implies that imports of Japanese automobile parts will be positively related to production of automobiles by

${ }^{9}$ Okamoto (1998) finds evidence that U.S. firms purchase Japanese-produced automobile parts.

${ }^{10}$ The assumption of production at capacity seems more reasonable for these data than for most because of the rapid growth of Japanese auto-related plants in the United States during this time period. Blonigen and Tomlin (1998) find employee levels of Japanese auto-related plants in the United States more than doubled on average from 1987 to 1990. 
both Japanese- and U.S.-owned producers and perfectly replaced or substituted by local production, controlling for relative price changes.

I use this simple model because of the data limitations I face. A richer model would specify the supply side in more detail with attention to cost side factors, as well as the supplying industry's specific trade-off between local production and exports. Equation (2) implies that a firm always operates local production at capacity and any changes in demand conditions will be reflected in how much is exported to the market. To the extent that the firm would alter both local production and exports in the same direction in response to demand changes (e.g., reduce production in both locales in response to lower demand) there is an endogeneity bias toward finding complementarity, not substitution as hypothesized.

To test, I assume there are three types of inputs into automobile production: auto parts produced by Japanese-owned establishments, auto parts produced by U.S.-owned establishments, and capital. The associated factor prices are $\mathrm{w}_{\mathrm{J}}, \mathrm{w}_{\mathrm{US}}$, and $\mathrm{r}$, respectively. If factor demands are homogeneous of degree zero in factor prices, I can rewrite equation (2) as

$$
X_{J M P}^{D}=X_{J}^{D}\left(\frac{w_{J}}{w_{U S}}, \frac{r}{w_{U S}}, Y_{J}, Y_{U}\right)-X_{J P}
$$

Because of the small number of observations ( 14 annual for each automobile part), I specify a linear version of equation (3) for testing each of the ten automobile part equations:

$$
\left[\mathrm{x}_{\mathrm{JIMP}}\right]_{\mathrm{t}}=\gamma_{0}+\gamma_{1}\left[\frac{\mathrm{w}_{\mathrm{J}}}{\mathrm{w}_{\mathrm{US}}}\right]_{\mathrm{t}}+\gamma_{2}\left[\frac{\mathrm{r}}{\mathrm{w}_{\mathrm{US}}}\right]_{\mathrm{t}}+\gamma_{3}\left[\mathrm{Y}_{\mathrm{J}}\right]_{\mathrm{t}}+\gamma_{4}\left[\mathrm{Y}_{\mathrm{US}}\right]_{\mathrm{t}}+\gamma_{5}\left[\mathrm{X}_{\mathrm{JP}}\right]_{\mathrm{t}}+\epsilon_{\mathrm{t}}
$$


where the variables are defined as above, $\epsilon_{1}$ is a normally distributed error term and the $\gamma s$ are parameters to be estimated. If data on Japanese local production of auto parts were available, the estimated coefficient on $\gamma_{5}$ is hypothesized to equal -1 ; i.e., a pure substitution effect. Instead, I only know employment levels of Japanese-owned affiliate auto parts plants in the United States and necessarily use these employment data (measured in hundreds of employees) to proxy for production data. ${ }^{11}$ These data come from the Japan Economic Institute publication Japan's Expanding U.S. Manufacturing Presence, various issues through 1990. Because I use employment data, rather than production data, there is no reason to expect $\gamma_{5}$ to equal -1 in the estimation below, though clearly it is hypothesized to be negative in sign. Japanese import quantities $\left(\mathrm{x}_{\mathrm{IMP}}\right)$ and prices $\left(\mathrm{w}_{\mathrm{J}}-\right.$ measured as unit values) are taken from the NBER import database. Because $w_{J}$ is expressed in U.S. dollars, it implicitly takes into account not only exchange rate changes, but also firms' "pass through" of those changes to the U.S. market. U.S. automobile part prices $\left(\mathrm{w}_{\mathrm{US}}\right)$ and the price of capital ( $\mathrm{r}$ ) come from Bureau of Labor Statistics producer price indexes and the Economic Report of the President, respectively. Automobile production data in the United States measured in millions of vehicles $\left(\mathrm{Y}_{\mathrm{J}}\right.$ and $\left.\mathrm{Y}_{\mathrm{US}}\right)$ come from

\section{Ward's Auto World.}

Table 2 reports estimation results using Zellner's iterative SUR technique on the ten automobile part equations. SUR methodology is justified by the distinct possibility that there were economywide or industry shocks that would affect the disturbance terms of all automobile

${ }^{11}$ Clearly, some proportion of employees in any manufacturing plant are not directly involved in production, but to the extent that this proportion is similar across plants in a product, this implies only a scaling issue with this variable. In addition, I directly contacted the Japaneseowned U.S. plants in both sets of regressions (automobile parts and consumer products) to verify that they indeed were manufacturing plants, and not distribution or retail operations. 
part regressions, so that they are contemporaneously correlated. While OLS gave qualitatively similar results, SUR generally improved the precision of the coefficient estimates.

All ten equations have F-statistics significant at the 95 percent confidence level and reasonable adjusted $\mathrm{R}$-squareds. For sake of space, the constant and coefficients on the relative prices are not reported in table 2 , but were generally estimated with precision and correct signs. Both hypothesized relationships between trade and foreign production by the Japanese find strong support. Japanese automobile parts production in the United States has a statistically significant negative relationship on U.S. imports of Japanese automobile parts at the 95 percent confidence level in nine of the ten equations, with correct signs in all of them. The strength of the estimated substitution between trade and foreign production in these product-level regressions is in sharp contrast to previous empirical work.

The results also show a strong positive relationship between Japanese automobile production in the United States and imported Japanese automobile parts: nine of the ten have tstatistics at the 95 percent confidence level. Thus, as expected, vertical industrial relationships are associated with strong complementary relationships between exports and foreign production at the product level. The relationship between automobile production by U.S.-owned automobile manufacturers and imports of Japanese automobile parts is less strong in general, as one might expect, but does show a strong positive relationship in automotive glass products, radio cassette players, engine coils, and bumpers and parts.

The coefficients relating foreign production and exports are economically significant as well. For example, estimated coefficients in laminated safety glass imply that an extra 100 employees in U.S. production by Japanese firms means 194,000 square feet less annual exported 
laminated safety glass, while an extra 100,000 Japanese autos produced in the United States translates into an increase of 713,300 square feet in annual exports from Japan. An extra 100 employees in U.S. production of door locks leads to 116,000 less exported door locks from Japan, while an additional 100,000 Japanese autos produced in the United States increases exports by 101,300 door locks. ${ }^{12}$

Of course, there is the possibility of specification bias with these estimates. One source of concern is the time-series properties of the data. However, the Durbin-Watson statistics generally do not indicate autocorrelation across the equations, and when the system was reestimated allowing for an AR1 process, results are qualitatively unchanged. A second concern is endogeneity of the Japanese automobile production in the United States variable. It is not clear which way this bias may affect the estimates. On one hand, there may be a third factor, such as growth in demand that may increase both exports and foreign affiliate production. In this case, as previous literature has argued and found (Grubert and Mutti, 1991), endogeneity is likely to bias the estimates toward finding complementarity, not substitution. On the other hand, there may be a third factor such as exchange rate or tariff changes that would simultaneously move the exports and foreign affiliate production in opposite fashion, which would bias toward finding substitution. Unfortunately, the small number of observations here makes correction techniques for endogeneity inappropriate in the sense that they rely on asymptotic properties for consistency and

${ }^{12}$ The estimated coefficients on Japanese automobile production in the United States seem higher than they should be for a number of products. However, for these products the coefficient may be capturing the effect of exports being used as replacement parts in the United States, rather than for construction of new autos. Because of degrees of freedom and collinearity problems it is difficult to control for this in the estimation. 
efficiency, with unknown small-sample properties. ${ }^{13}$ Specification bias could also come from measurement error in my variables, including reliance on import unit values for price data (e.g., see Feenstra and Shiells [1994]). Despite these various issues, none necessarily suggest that the estimates should be systematically biased toward finding substitution.

\subsection{Testing for substitution with final consumer products}

While the above results on automobile parts cleanly separates out significant complementarity and substitution effects, it may be of interest to see if product-level data works well at identifying a substitution effect of affiliate production for other types of products as well. In particular, Japanese automobile manufacturers in the United States were under political pressure to increase domestic content, and in response, investment by Japanese-owned automobile parts suppliers into the United States was quite substantial in the last half of the 1980s. This may have intensified substitution effects of foreign production for exports in the case of these goods and calls into question the generality of the results. Therefore, this section tests for substitution between Japanese exports and affiliate production in the United States using product-level, timeseries data on eleven final consumer products which were not subject to such U.S. government scrutiny over this time period.

${ }^{13}$ Despite these concerns, I estimated the system using three-stage least squares, instrumenting for both the local production variable and the price term. I tried a number of possible instrument matrices which included the yen-dollar exchange rate, contemporaneous and lagged levels of total Japanese manufacturing employees in the United States, and the discount rate in Japan. Results from the three-stage least squares regression were qualitatively similar to those reported in table 2. Most estimates on local production increased, which supports the notion that the substitution coefficients are biased downward in those instances. These results are available upon request from the author. 


\subsection{Descriptive analysis}

I look for substitution of local production for exports using separate time-series data on eleven final consumer products: 1) hand-held vacuum cleaners, 2) other vacuum cleaners, 3) microwave ovens, 4) grand pianos, 5) other pianos, 6) music synthesizers, 7) sake, 8) soy sauce, 9) ballpoint pens, 10) golf balls, and 11) golf clubs. This list of products is the result of a number of considerations. First, the focus is on products not involved in significant U.S. trade protection, because one could argue that substitution effects will be unnaturally large with these products as firms "tariff jump" the trade protection. Second, I was concerned about using intermediate goods, because it is often difficult to control for the derived demand coming from various downstream industries. With auto parts this vertical relationship is clear and the mapping is fairly clean from automobile parts to automobiles. But for intermediates goods like steel, semiconductors, engines, chemicals, etc., the vertical relationship is far from clean. Thus, I focus specifically on consumer products for final consumption. Final additional constraints were finding products with some FDI in the United States and being able to map the product-level export data over time, especially the switch in 1989 from the TSUSA to HTS import classification schemes, as discussed above. This issue of mapping proved especially difficult for certain products, such as consumer electronics, as there were often a number of changes in how these products were classified over time.

The data for these eleven consumer products come from the same sources as for the automobile parts regressions. Import data come from the NBER U.S. import database described in Feenstra (1996), while data on local production by Japanese firms in the United States come from the Japan Economic Institute publications, Japan's Expanding U.S. Manufacturing Presence. Unlike the automobile parts data, the import data for the consumer products often 
remained consistent further back in time (with the exception of data for golf clubs and music synthesizers). Additionally, there were substantially less FDI occurrences of which to keep track for these products, so it was feasible to update local employee numbers beyond 1990, the ending date of my primary source. Thus, most of the time series run from 1972-1994, which are all the years covered by the NBER U.S. import database. See the data appendix for more details on data sources and construction.

Figures 4A through 4D plot Japanese exports and U.S. production by Japanese firms over time for four of the eleven final consumer products. Once again, for the sake of space I only present four products where the substitution effects appear substantial, but plots of the remaining products are available form the author upon request. In addition, a number of the products not shown display plausible negative correlation between exports and level of U.S. affiliate employees. Thus, as with many of the automobile part products, the data often reveal not just substitution effects for these final consumer products, but large substitution effects. However, these plots do not control for other factors that may affect the level of exports into the United States, so I next turn to regression analysis.

\subsubsection{Regression analysis}

As noted above, examination of final consumer products means that there is no vertical production relationship for which to control. Thus, the derived demand model used in section 3 above to indicate an empirical framework for automobile parts is not applicable here. Instead, I begin simply with the following reduced form demand equation for each Japanese product: 


$$
\mathrm{EX}_{\mathrm{t}}+\mathrm{LP}_{\mathrm{t}}=\alpha+\beta_{1} \mathrm{P}_{\mathrm{t}}+\beta_{2} \mathrm{INC}_{\mathrm{t}}+\epsilon_{\mathrm{t}}
$$

where EX is Japanese exports to the United States, LP is local production by Japanese affiliates in the United States, $P$ is the price of the Japanese product, INC is income of U.S. consumers measured by real U.S. GDP, and $\epsilon$ is an assumed normally distributed error term. To test the relationship between EX and LP, I can simply move $L P_{t}$ to the right side of (5) and expect a coefficient of -1 if there is only a pure substitution effect. However, as with the automobile parts regressions above, I do not have data on local production, but only employees used for local production. If we assume there is a linear time-invariant relationship between local production and local employees (LE) of the form, $L P_{t}=\beta_{3} L E_{t}$, equation (5) becomes

$$
\mathrm{EX}_{\mathrm{t}}=\alpha+\beta_{1} \mathrm{P}_{\mathrm{t}}+\beta_{2} \mathrm{HNC}_{\mathrm{t}}+\beta_{3} \mathrm{LE}_{\mathrm{t}}+\epsilon_{\mathrm{t}}
$$

The expected sign on $\beta_{2}$ is positive, while I expect negative signs for $\beta_{1}$ and $\beta_{3}$.

The above specification is admittedly parsimonious -- I have assumed a linear reduced form demand model with local production as a perfect substitute for the exported good. However, this approach is justified by the small number of observations I can employ for estimating each product's demand. While misspecification bias may cause inefficient estimates (i.e. higher standard errors), if it systematically biases the coefficient estimate on LE, it should be toward not finding substitution. This is because, first, any demand-increasing effect from locating production in the United States (such as proximity advantages) is not separately modeled or identified from the substitution effect. Second, there is the same endogeneity concern with 
respect to local production as encountered with the automobile parts equations. ${ }^{14}$

Table 3 reports SUR regression results for the eleven consumer products using equation (6) as the testing specification. Because the data for golf clubs and music synthesizers do not begin until 1979, all product equations in table 3 are estimated with 16 annual observations running from 1979-1994. Below I report results from estimating the other nine products as a SUR system with annual data that goes back to 1972 . Overall, the regressions reported in table 3 perform well. Ten of the eleven equations have F-tests that reject the null hypothesis of zero coefficients at the 95 percent confidence level or higher. In addition, all coefficients on the price and income terms are as expected (except for income in the microwave ovens equation) with many statistically significant. This suggests that these are decently identified demand equations.

There is support for substitution effects across these products as well. Nine of the eleven regressions show a negative relationship between U.S. production by Japanese firms and Japanese exports of these products to the United States, with seven of these statistically significant at standard confidence levels. Only ballpoint pens display a statistically significant positive effect of local production on the exported good. As with the automobile parts regressions, the coefficients can be used to gauge the magnitude of the substitution effect. For example, an additional 100 employees involved in U.S. production of golf galls reduces U.S. imports by 1.757 million dozen,

${ }^{14}$ There is also the concern of endogeneity with the price term and properly identifying a demand equation. However, all price terms have correct signs in the regressions reported in table 3 using OLS. I also estimated the system of equations using three-stage least squares estimation and the using the same instruments as those used for the auto parts three-stage least squares regression discussed in footnote 13 . These results were qualitatively similar to those reported in table 3 and are available from the author upon request. I also tried specifying and testing a Japanese export supply equation in place of equation (6). While the variables used to explain demand in (6) almost always had correct signs and explained the data nicely without instrumenting for price, this was rarely true for various supply equation specifications I tried. 
whereas 100 additional U.S. employees lowers U.S. sake imports by 681,000 gallons. While caution should be made in interpreting these coefficients because of specification and sample size, these magnitudes seem plausible.

As mentioned earlier, there may be a number of sources of specification bias. Again, a source of concern that may be correctable with the limited number of observations is the timeseries properties of the data. With these regressions, the majority of the Durbin-Watson statistics indicate possible serial correlation. Thus, the coefficients in table 3 are estimated with an AR1 correction. The majority of equations yield a statistically significant correlation between periods, yet qualitatively, results are quite similar across the equations regardless of whether there is an ARl correction or not. ${ }^{15}$

While the effect of exchange rate movements (and firms' pass through decisions) are controlled for through the import price term in these regressions, there may be concern that other macroeconomic (besides U.S. GDP) or industry trends may be driving these estimates. Table 4 reports how sensitive the effect of Japanese production in the United States on Japanese exports to the United States is for a few alternative specifications that control for other general economic effects. Column 1 of table 4 reports the coefficient on Japanese production in the United States obtained from the base specification used in table 3. This is reported in order to compare results across alternative specifications. Column 2 of table 4 reports the coefficient on Japanese production in the United States when I include a linear time trend to the base specification. The

${ }^{15}$ A number of the estimated ARl correlations are quite large and cannot reject a correlation of one, which would suggest a unit root. I estimated all eleven equations in first differences. For the majority of equations an F-test rejects the first-differences specification. For the two equations where the first-differences specification is accepted, results are qualitatively identical to the levels regressions. 
time trend is statistically significant for a number of equations, but it has little impact on our coefficient of interest for most products. The exception is soy sauce, which changes signs from positive to negative, but is still estimated imprecisely.

Perhaps the exports of these final consumer products are behaving in a similar manner to other products in their associated industry. Or in other words, if one plotted Japanese exports of other products in the same industry for which there is U.S.-based Japanese production, would one get similar plots to the products estimated in table 3? To control for this, column 3 of table 4 reports the coefficient on Japanese production in the United States when I include both a linear time trend and a variable capturing the quantity of Japanese exports to the United States in the product's 4-digit SIC industry. ${ }^{16}$ This industry variable is constructed by taking the export value of the associated 4-digit industry minus the product's export value, converting this to yen and deflating by a Japanese export price index. In this manner, one can construct a measure of the associated industry's "quantity" movements. Because of data availability on the industry quantity variable, the data now span the period 1979-1992 (see data appendix for more details). For most of the products, this specification yields almost identical results to the base specification. ${ }^{17}$ The exceptions are soy sauce and ball point pens which now yield results more consistent with a substitution effect. Soy sauce now displays a statistically significant negative correlation between

${ }^{16}$ An alternative analysis would be to gather data on other products in these industries for which there was no U.S.-based Japanese production and create plots similar to tables 4A through 4D. This would be an immensely time consuming process and many products would have TSUSA to HTS mapping problems.

${ }^{17}$ While I do not report the coefficients on the industry quantity controls because of space limitations, many of them are statistically significant. Interestingly, there were nearly as many with a negative sign, as with a positive sign. 
production in the United States and exports as hypothesized, and ballpoint pens no longer has a statistically significant positive correlation. In summary, table 4 shows the relative insensitivity of the estimates on Japanese production in the United States to these alternative specifications.

A final sensitivity test is to eliminate the music synthesizer and golf club equations from the SUR so that the number of observations for each equation can be expanded to start from 1972 rather than 1979. Given the limited number of observations for each equation in the base specification, this is obviously a large percentage increase in observations. Table 5 reports results from estimating the remaining nine products using SUR on 21 annual observations from 19721992. The estimates include an ARI correction, a time trend and industry quantity control for each equation, though these coefficients are not reported in the interest of space. Once again, results do not change significantly from estimates in tables 3 and 4 . Eight of the nine coefficients relating Japanese exports and Japanese production in the United States have a significant negative sign, with four statistically significant. ${ }^{18}$

\section{Conclusion}

This paper was motivated by the many empirical studies showing complementarity between exports and foreign production. Why is it so difficult to find substitution effects? Previous papers had explored statistical concerns, including endogeneity and aggregation bias.

${ }^{18}$ Another concern raised by a referee is that Japanese firms may have began substantial production of these products in other countries, using these countries as export platforms to the United States. Since my dependent variable only measures exports from Japan, this could bias the substitution effects I find. Upon the referee's suggestion I examined the behavior of U.S. imports from other Asian countries in the eleven consumer products during this time period, but found no systematic trends indicating increased exports to the United States from these other Asian countries as Japanese exports to the United States fell. 
This paper provides evidence that aggregation bias may be playing a large role. I show substitution effects are relatively easy to identify in product-level data. In fact, product-level data allows one to separately identify substitution from complementarity effects (here from vertical production relationships), rather than try to infer them from estimates using more aggregate data. In this sense, the paper highlights the importance of matching the level of data aggregation with the hypotheses being tested. This is particularly true at a time when there is an increasing proliferation of available microeconomic data in the field of international economics.

There are a number of extensions that can follow from this paper. First, while I was able to separately test for complementarity from vertical production relationships, my data do not allow a test of complementarity from other channels mentioned in the literature, such as demand complementarities across a firm's related products. Thus, there is room for future work to identify and estimate the magnitude of these effects. Second, there is more work to be done to interpret the large shifts in local production versus exports this paper finds for many products. This paper's analyses (particularly the simple plots) shows that substitution of foreign production for exports often are large one-time shifts, not gradual changes over time. Many of the products, including the final consumer products not subject to new U.S. protection during the sample, show precipitous decreases in exports to the United States once production in the United States began. This may suggest that within product lines, firms' choice of exports and foreign production is to some extent an "either/or" decision, as often assumed by theoretical models of MNCs. However, it is also apparent that there is not complete replacement of exports by local production for the products I analyze. Thus, firms may be choosing to have some combination of both to serve a market. One possible reason for this would be to hedge against exchange rate risk, as suggested 
by Goldberg and Kolstad (1994). On the other hand, if there are multiple firms represented by my product level data, there may be both positive exports and local production at the product level, because some firms in the product line are serving the market with solely local production, while other firms in the product line are solely exporting. This suggests there is a need for future work with product-level data by firm to resolve some of these important questions. 


\section{References}

Belderbos, Rene and Leo Sleuwaegen. (1998) "Tariff Jumping DFI and Export Substitution: Japanese Electronics Firms in Europe," International Journal of Industrial Organization. 16: 601-638.

Blomström, Magnus, Robert E. Lipsey, and Ksenia Kulchycky. (1988) "U.S. and Swedish Direct Investment and Exports," in R.E. Baldwin (Ed.), Trade Policy Issues and Empirical Analysis. Chicago: University of Chicago Press, 259-97.

Blonigen, Bruce A. and KaSaundra Tomlin. (1998) "Size and Growth of Japanese Plants in the United States," mimeo.

Brainard, S. Lael. (1993) "A Simple Theory of Multinational Corporations and Trade with a Trade-off between Proximity and Concentration," NBER Working Paper No. 4269.

Brainard, S. Lael. (1997) “An Empirical Assessment of the Proximity-Concentration Trade-off Between Multinational Sales and Trade," American Economic Review. 87(4): 520-544.

Buckley, Peter J. and Mark Casson. (1981) "The Optimal Timing of Foreign Direct Investment," Economic Journal. 91: 75-87.

Clausing, Kimberly. (forthcoming) "Does Multinational Activity Displace Trade?" Economic Inquiry.

Dunning, John H. (1981) International Production and the Multinational Enterprise. London: George Allen and Unwin.

Feenstra, Robert C. (1996) "U.S.Imports, 1972-1994: Data and Concordances," NBER Working Paper No. 5515.

Feenstra, Robert C. and Clinton R. Shiells. (1994) "Bias in U.S. Import Prices and Demand," NBER Working Paper No. 4841.

Goldberg, Linda S. and Charles D. Kolstad. (1994) "Foreign Direct Investment, Exchange Rate Variability and Demand Uncertainty," NBER Working Paper No. 4815.

Graham, Edward M. (forthcoming) "The Relationships Between Trade and Foreign Direct Investment in the Manufacturing Sector: Empirical Results for the United States and Japan," in Dennis Encarnation (ed.), Does Ownership Matter?: Japanese Multinationals in East Asia. London: Oxford University Press. 
Grubert, Harry, and John Mutti. (1991) "Taxes, Tariffs, and Transfer Pricing in Multinational Corporate Decision Making," Review of Economics and Statistics. 73(May): 285-293.

Head, Keith and John Ries. (1997) “Overseas Investment and Firm Exports,” mimeo.

Lipsey, Robert E., and Merle Yahr Weiss. (1981) "Foreign Production and Exports in Manufacturing Industries," Review of Economics and Statistics. 63(Nov): 488-494.

Lipsey, Robert E., and Merle Yahr Weiss. (1984) "Foreign Production and Exports of Individual Firms," Review of Economics and Statistics. 66(May): 304-307.

Markusen James R. (1983) "Factor Movements and Commodity Trade as Complements," Journal of International Economics. 14: 341-356.

Markusen, James R. (1984) "Multinationals, Multi-plant Economies, and the Gains from Trade," Journal of International Economics. 16(3-4): 205-26.

Markusen, James R. (1995) “The Boundaries of Multinational Enterprises and the Theory of International Trade," Journal of Economic Perspectives, Vol. 9(2): 169-89.

Mundell, Robert A. (1957) "International Trade and Factor Mobility," American Economic Review. Vol. 47: 321-35.

Okamoto, Yumiko. (1998) "Multinationals, Production Efficiency and Spillover Effects: The Case of the U.S. Auto Parts Industry," mimeo.

Rugman, Alan M. (1990) Multinationals and Canada-United States Free Trade. Columbia, SC: University of South Carolina Press.

Swedenborg, Birgitta. (1979) The Multinational Operations of Swedish Firms. Stockholm: The Industrial Institute for Economic and Social Research.

Swedenborg, Birgitta. (forthcoming) "Determinants and Effects of MNC Growth: The Swedish Case Revisited," in Magnus Blomstrom and Linda Goldberg (Eds.), Topics in Empirical International Economics. Chicago: University of Chicago Press (NBER).

Swenson, Deborah L. (1997) "Explaining Domestic Content: Evidence from Japanese and U.S. Automobile Production in the United States," in Robert C. Feenstra (Ed.), Effects of U.S. Trade Protection and Promotion Policies. Chicago: University of Chicago Press (NBER), 33-53.

Swenson, Deborah L. (1998) "Foreign Investment and the Mediation of Trade Flows," mimeo. 
Williamson, Oliver E. (1975) Markets and Hierarchies, Analysis and Antitrust Implications: A Study in the Economics of Internal Organization. New York: Free Press.

Wong, Kar-yiu. (1986) “Are International Trade and Factor Mobility Substitutes?” Journal of International Economics. 21:25-43.

Yamawaki, Hideki. (1991) "Exports and Foreign Distributional Activities: Evidence on Japanese Firms in the United States," Review of Economics and Statistics. 73(May): 294-300. 
TABLE 1: Japanese foreign direct investment flows into the United States for automobile parts and manufacturing, 1980-1990, various years.

\begin{tabular}{lccc}
\hline \hline & $\begin{array}{l}\text { Number of new } \\
\text { Japanese-owned } \\
\text { automobile parts } \\
\text { plants in the United } \\
\text { States }\end{array}$ & $\begin{array}{l}\text { Number of employees in } \\
\text { new Japanese-owned } \\
\text { automobile parts plants in } \\
\text { the United States }\end{array}$ & $\begin{array}{l}\text { New U.S. employees } \\
\text { for all Japanese-owned } \\
\text { manufacturing plants }\end{array}$ \\
\hline 1980 & 2 & 100 & 5,232 \\
1984 & 1 & 50 & 16,940 \\
1986 & 23 & 2,817 & 23,640 \\
1987 & 47 & 8,583 & 39,952 \\
1988 & 54 & 13,697 & 74,801 \\
1989 & 64 & 15,171 & 80,800 \\
1990 & 36 & 6,734 & 31,772 \\
\hline
\end{tabular}

Notes: Plant and employee numbers are for year of entry. All data include new plants, acquisitions, and joint ventures, as well as plants with various shares of ownership, though the vast majority are fully- or majority-owned. There were a handful of cases where employee numbers for certain plants were imputed because of missing data the year of entry or because employee numbers were reported for a group of plants rather than an individual plant.

Source: Japan Economic Institute. Japan's Expanding Manufacturing Presence in the United States, various issues. 
TABLE 2: SUR regressions of import demand for Japanese automobile parts, 1978-91.

\begin{tabular}{|c|c|c|c|c|c|}
\hline $\begin{array}{c}\text { Dependent } \\
\text { Variable }\end{array}$ & $\begin{array}{c}\text { Japanese } \\
\text { auto part } \\
\text { production } \\
\text { in the U.S }\end{array}$ & $\begin{array}{l}\text { Japanese } \\
\text { automobile } \\
\text { production } \\
\text { in the U.S. }\end{array}$ & $\begin{array}{c}\text { U.S. } \\
\text { domestic } \\
\text { automobile } \\
\text { production }\end{array}$ & $\begin{array}{c}\text { Adjusted } \\
\mathrm{R}^{2} \\
\end{array}$ & $\mathrm{~F}$ test \\
\hline Toughened glass & $\begin{array}{l}-0.199 * * * \\
(0.000)\end{array}$ & $\begin{array}{l}8.609 * * * \\
(0.000)\end{array}$ & $\begin{array}{c}0.419^{* *} \\
(0.017)\end{array}$ & 0.92 & $\begin{array}{l}23.15^{* * *} \\
(0.000)\end{array}$ \\
\hline Laminated safety glass & $\begin{array}{l}-0.194^{* * *} \\
(0.000)\end{array}$ & $\begin{array}{l}7.133^{* * * *} \\
(0.000)\end{array}$ & $\begin{array}{c}0.348^{* *} \\
(0.019)\end{array}$ & 0.69 & $\begin{array}{l}6.86^{* * * *} \\
(0.009)\end{array}$ \\
\hline Automotive mirrors & $\begin{array}{l}-2.048^{* * * *} \\
(0.000)\end{array}$ & $\begin{array}{l}6.949^{* * *} \\
(0.000)\end{array}$ & $\begin{array}{c}-0.392 * * \\
(0.036)\end{array}$ & 0.91 & $\begin{array}{l}28.74 * * * \\
(0.000)\end{array}$ \\
\hline Radio-cassette players & $\begin{array}{l}-0.363^{* * *} \\
(0.000)\end{array}$ & $\begin{array}{l}2.053^{* * *} \\
(0.000)\end{array}$ & $\begin{array}{c}0.260^{*} \\
(0.054)\end{array}$ & 0.75 & $\begin{array}{l}8.87^{* * *} \\
(0.004)\end{array}$ \\
\hline Radio receivers & $\begin{array}{l}-0.030 * * * \\
(0.000)\end{array}$ & $\begin{array}{c}0.215 \\
(0.257)\end{array}$ & $\begin{array}{r}-0.019 \\
(0.616)\end{array}$ & 0.79 & $\begin{array}{l}10.81^{* * *} \\
(0.002)\end{array}$ \\
\hline Engine starters & $\begin{array}{l}-0.283^{* * *} \\
(0.000)\end{array}$ & $\begin{array}{l}7.039 * * * \\
(0.000)\end{array}$ & $\begin{array}{c}0.091 \\
(0.315)\end{array}$ & 0.65 & $\begin{array}{c}5.91^{* *} \\
(0.014)\end{array}$ \\
\hline Engine coils & $\begin{array}{c}-0.117 * * * \\
(0.000)\end{array}$ & $\begin{array}{l}4.806^{* * *} \\
(0.000)\end{array}$ & $\begin{array}{c}0.121 * \\
(0.055)\end{array}$ & 0.89 & $\begin{array}{l}21.34 * * * \\
(0.000)\end{array}$ \\
\hline Door locks & $\begin{array}{l}-0.116^{* * *} \\
(0.000)\end{array}$ & $\begin{array}{l}1.013^{* * *} \\
(0.000)\end{array}$ & $\begin{array}{c}-0.031 \\
(0.128)\end{array}$ & 0.92 & $\begin{array}{l}29.12^{* * *} \\
(0.000)\end{array}$ \\
\hline Bumpers and parts & $\begin{array}{l}-0.021 * * \\
(0.039)\end{array}$ & $\begin{array}{l}0.589^{* *} \\
(0.019)\end{array}$ & $\begin{array}{l}0.335^{* * *} \\
(0.000)\end{array}$ & 0.67 & $\begin{array}{c}6.21^{* *} \\
(0.012)\end{array}$ \\
\hline Seats and parts & $\begin{array}{c}-0.068 \\
(0.152)\end{array}$ & $\begin{array}{l}1.760^{* * * *} \\
(0.000)\end{array}$ & $\begin{array}{c}-0.080 \\
(0.459)\end{array}$ & 0.91 & $\begin{array}{l}26.71^{* * *} \\
(0.000)\end{array}$ \\
\hline
\end{tabular}

Notes: P-values are in parentheses. ${ }^{* * *},{ }^{* *}$ and $*$ denote a t-statistic at the one, five and ten percent significance levels, respectively. All equations are estimated from 14 annual observations (1978-1991) using Zellner's iterative Seemingly Unrelated Regressions (SUR) technique. 
TABLE 3: SUR regressions of import demand for Japanese final consumer products, 1979-94.

\begin{tabular}{|c|c|c|c|c|c|}
\hline $\begin{array}{l}\text { Dependent } \\
\text { Variable } \\
\end{array}$ & Price & Income & $\begin{array}{l}\text { Japanese } \\
\text { production } \\
\text { in the U.S. }\end{array}$ & $\begin{array}{l}\text { Adj. } \\
\mathrm{R}^{2} \\
\end{array}$ & F-test \\
\hline Hand vacuum cleaners & $\begin{array}{l}-0.001 * * * \\
(0.001)\end{array}$ & $\begin{array}{l}0.055^{* * * *} \\
(0.008)\end{array}$ & $\begin{array}{l}-0.005^{* * *} \\
(0.000)\end{array}$ & 0.50 & $\begin{array}{c}5.96^{* *} \\
(0.010)\end{array}$ \\
\hline Other vacuum cleaners & $\begin{array}{l}-0.005^{* * *} \\
(0.000)\end{array}$ & $\begin{array}{l}0.419 * * * \\
(0.000)\end{array}$ & $\begin{array}{l}-0.021^{* * *} \\
(0.000)\end{array}$ & 0.73 & $\begin{array}{l}14.32^{* * *} \\
(0.000)\end{array}$ \\
\hline Microwave ovens & $\begin{array}{l}-0.039 * * * \\
(0.000)\end{array}$ & $\begin{array}{l}-1.870^{*} \\
(0.100)\end{array}$ & $\begin{array}{c}-0.856 \\
(0.110)\end{array}$ & 0.56 & $\begin{array}{l}7.37^{* * * *} \\
(0.005)\end{array}$ \\
\hline Grand pianos & $\begin{array}{l}-0.004^{* * *} \\
(0.000)\end{array}$ & $\begin{array}{l}0.010^{* * * *} \\
(0.000)\end{array}$ & $\begin{array}{l}-0.002 * * \\
(0.023)\end{array}$ & 0.81 & $\begin{array}{l}16.76^{* * *} \\
(0.000)\end{array}$ \\
\hline Other pianos & $\begin{array}{c}-0.001 \\
(0.374)\end{array}$ & $\begin{array}{c}0.001 \\
(0.307)\end{array}$ & $\begin{array}{c}-0.001 \\
(0.254)\end{array}$ & -0.21 & $\begin{array}{c}0.12 \\
(0.949)\end{array}$ \\
\hline Music synthesizers & $\begin{array}{l}-0.245^{* * *} \\
(0.000)\end{array}$ & $\begin{array}{l}0.081^{* * *} \\
(0.004)\end{array}$ & $\begin{array}{c}-0.035^{*} \\
(0.074)\end{array}$ & 0.45 & $\begin{array}{c}5.10^{* *} \\
(0.016)\end{array}$ \\
\hline Sake & $\begin{array}{l}-0.332 * * * \\
(0.000)\end{array}$ & $\begin{array}{l}0.492^{* * * *} \\
(0.000)\end{array}$ & $\begin{array}{l}-0.681 * * * \\
(0.000)\end{array}$ & 0.92 & $\begin{array}{l}56.90^{* * *} \\
(0.000)\end{array}$ \\
\hline Soy sauce & $\begin{array}{c}-0.796 \\
(0.489)\end{array}$ & $\begin{array}{l}4.348 * * * \\
(0.000)\end{array}$ & $\begin{array}{c}1.850 \\
(0.139)\end{array}$ & 0.90 & $\begin{array}{l}44.75^{* * *} \\
(0.000)\end{array}$ \\
\hline Ballpoint pens & $\begin{aligned} &-381.58 * * * \\
&(0.001)\end{aligned}$ & $\begin{array}{l}142.18^{* * *} \\
(0.000)\end{array}$ & $\begin{array}{l}13.733 * * * \\
(0.000)\end{array}$ & 0.97 & $\begin{array}{l}144.02 * * * \\
(0.000)\end{array}$ \\
\hline Golf balls & $\begin{array}{c}-0.011 \\
(0.489)\end{array}$ & $\begin{array}{l}1.581^{* * * *} \\
(0.000)\end{array}$ & $\begin{array}{l}-1.757^{* * *} \\
(0.000)\end{array}$ & 0.90 & $\begin{array}{l}45.25 * * * \\
(0.000)\end{array}$ \\
\hline Golf clubs & $\begin{array}{l}-0.002 * * * \\
(0.007)\end{array}$ & $\begin{array}{l}0.256^{* * *} \\
(0.000)\end{array}$ & $\begin{array}{l}-0.069 * * \\
(0.026)\end{array}$ & 0.73 & $\begin{array}{l}14.22 * * * \\
(0.000)\end{array}$ \\
\hline
\end{tabular}

Notes: P-values are in parentheses. $* * *, * *$ and $*$ denote a t-statistic at the one, five and ten percent significance levels, respectively. All equations are estimated from 16 annual observations (1979-1994) using Zellner's iterative Seemingly Unrelated Regressions (SUR) technique and an ARI correction. Equations are estimated with a constant, but its coefficient is not reported here. 
TABLE 4: Coefficient on Japanese production in the U.S. for various SUR regressions of import demand for Japanese final consumer products, 1979-94.

\begin{tabular}{|c|c|c|c|}
\hline $\begin{array}{l}\text { Dependent } \\
\text { Variable } \\
\end{array}$ & $\begin{array}{c}\text { Table } 3 \\
\text { specification } \\
\end{array}$ & $\begin{array}{c}\text { Table } 3 \\
\text { specification } \\
\text { with trend }\end{array}$ & $\begin{array}{c}\text { Table } 3 \\
\text { specification with } \\
\text { trend and industry } \\
\text { quantity controls }\end{array}$ \\
\hline Hand vacuum cleaners & $\begin{array}{l}-0.005^{* * *} \\
(0.000)\end{array}$ & $\begin{array}{l}-0.007^{* * *} \\
(0.000)\end{array}$ & $\begin{array}{l}-0.009 * * * \\
(0.000)\end{array}$ \\
\hline Other vacuum cleaners & $\begin{array}{l}-0.021 * * * \\
(0.000)\end{array}$ & $\begin{array}{l}-0.021 * * * \\
(0.000)\end{array}$ & $\begin{array}{l}-0.025 * * * \\
(0.000)\end{array}$ \\
\hline Microwave ovens & $\begin{array}{c}-0.856 \\
(0.110)\end{array}$ & $\begin{array}{c}-0.472 \\
(0.329)\end{array}$ & $\begin{array}{l}-0.968 * * * \\
(0.000)\end{array}$ \\
\hline Grand pianos & $\begin{array}{l}-0.002 * * \\
(0.023)\end{array}$ & $\begin{array}{l}-0.003 * * * \\
(0.001)\end{array}$ & $\begin{array}{c}-0.001 \\
(0.448)\end{array}$ \\
\hline Other pianos & $\begin{array}{c}-0.001 \\
(0.254)\end{array}$ & $\begin{array}{l}-0.002^{* * *} \\
(0.000)\end{array}$ & $\begin{array}{c}-0.001 \\
(0.110)\end{array}$ \\
\hline Music synthesizers & $\begin{array}{c}-0.035^{*} \\
(0.074)\end{array}$ & $\begin{array}{c}-0.008 \\
(0.688)\end{array}$ & $\begin{array}{c}-0.027 \\
(0.110)\end{array}$ \\
\hline Sake & $\begin{array}{l}-0.681^{* * *} \\
(0.000)\end{array}$ & $\begin{array}{l}-0.723 * * * \\
(0.000)\end{array}$ & $\begin{array}{l}-0.750^{* * *} \\
(0.000)\end{array}$ \\
\hline Soy sauce & $\begin{array}{c}1.850 \\
(0.139)\end{array}$ & $\begin{array}{c}-1.861 \\
(0.280)\end{array}$ & $\begin{array}{l}-7.921^{* * *} \\
(0.000)\end{array}$ \\
\hline Ballpoint pens & $\begin{array}{l}13.733^{* * *} \\
(0.000)\end{array}$ & $\begin{array}{l}16.580 * * * \\
(0.000)\end{array}$ & $\begin{array}{c}-0.376 \\
(0.926)\end{array}$ \\
\hline Golf balls & $\begin{array}{c}-1.757^{* * *} \\
(0.000)\end{array}$ & $\begin{array}{l}-1.539 * * * \\
(0.000)\end{array}$ & $\begin{array}{l}-2.967 * * * \\
(0.000)\end{array}$ \\
\hline Golf clubs & $\begin{array}{l}-0.069^{* *} \\
(0.026)\end{array}$ & $\begin{array}{l}-0.073 * * \\
(0.022)\end{array}$ & $\begin{array}{l}-0.082 * * * \\
(0.007) \\
\end{array}$ \\
\hline
\end{tabular}

Notes: P-values are in parentheses. ${ }^{* * *},{ }^{* *}$ and $*$ denote a t-statistic at the one, five and ten percent significance levels, respectively. All equations are estimated from 16 annual observations (1979-1994) using Zellner's iterative Seemingly Unrelated Regressions (SUR) technique and an ARl correction. Equations are estimated with a constant, but its coefficient is not reported here. 
TABLE 5: SUR regressions of import demand for Japanese final consumer products, 1972-92.

\begin{tabular}{|c|c|c|c|c|c|}
\hline $\begin{array}{l}\text { Dependent } \\
\text { Variable } \\
\end{array}$ & Price & Income & $\begin{array}{l}\text { Japanese } \\
\text { production } \\
\text { in the U.S. }\end{array}$ & $\begin{array}{c}\text { Adj. } \\
\mathrm{R}^{2}\end{array}$ & F-test \\
\hline Hand vacuum cleaners & $\begin{array}{l}-0.003^{* * *} \\
(0.001)\end{array}$ & $\begin{array}{l}0.065^{* * *} \\
(0.005)\end{array}$ & $\begin{array}{l}-0.006^{* * *} \\
(0.000)\end{array}$ & 0.44 & $\begin{array}{c}4.14 * * \\
(0.015)\end{array}$ \\
\hline Other vacuum cleaners & $\begin{array}{c}-0.001 \\
(0.606)\end{array}$ & $\begin{array}{l}0.247^{* * *} \\
(0.000)\end{array}$ & $\begin{array}{l}-0.016^{* * *} \\
(0.000)\end{array}$ & 0.78 & $\begin{array}{l}15.07 * * * \\
(0.000)\end{array}$ \\
\hline Microwave ovens & $\begin{array}{l}-0.016^{* * *} \\
(0.000)\end{array}$ & $\begin{array}{c}0.572 \\
(0.141)\end{array}$ & $\begin{array}{c}-0.271 \\
(0.294)\end{array}$ & 0.90 & $\begin{array}{l}36.77^{* * * *} \\
(0.000)\end{array}$ \\
\hline Grand pianos & $\begin{array}{l}-0.000 * * * \\
(0.000)\end{array}$ & $\begin{array}{l}0.008^{* * * *} \\
(0.000)\end{array}$ & $\begin{array}{c}-0.001 \\
(0.530)\end{array}$ & 0.88 & $\begin{array}{l}30.93^{* * * *} \\
(0.000)\end{array}$ \\
\hline Other pianos & $\begin{array}{l}-0.000^{* *} \\
(0.016)\end{array}$ & $\begin{array}{c}-0.000 \\
(0.986)\end{array}$ & $\begin{array}{c}0.001 \\
(0.904)\end{array}$ & 0.13 & $\begin{array}{c}1.58 \\
(0.225)\end{array}$ \\
\hline Sake & $\begin{array}{l}-0.374^{* * *} \\
(0.000)\end{array}$ & $\begin{array}{l}0.508^{* * *} \\
(0.000)\end{array}$ & $\begin{array}{l}-0.587^{* * * *} \\
(0.000)\end{array}$ & 0.95 & $\begin{array}{l}73.28^{* * *} \\
(0.000)\end{array}$ \\
\hline Soy sauce & $\begin{array}{c}0.456 \\
(0.922)\end{array}$ & $\begin{array}{l}10.503^{* * *} \\
(0.000)\end{array}$ & $\begin{array}{c}-15.490^{* * * *} \\
(0.000)\end{array}$ & 0.76 & $\begin{array}{l}13.55^{* * *} \\
(0.000)\end{array}$ \\
\hline Ballpoint pens & $\begin{array}{c}-600.59 * * * \\
(0.000)\end{array}$ & $\begin{array}{l}207.14^{* * *} \\
(0.000)\end{array}$ & $\begin{array}{c}-1.116 \\
(0.830)\end{array}$ & 0.97 & $\begin{array}{l}150.12 * * * \\
(0.000)\end{array}$ \\
\hline Golf balls & $\begin{array}{c}-0.055^{*} \\
(0.078)\end{array}$ & $\begin{array}{l}1.086^{* * *} \\
(0.000)\end{array}$ & $\begin{array}{c}-0.455 \\
(0.589)\end{array}$ & 0.87 & $\begin{array}{l}27.50 * * * \\
(0.000)\end{array}$ \\
\hline
\end{tabular}

Notes: P-values are in parentheses. ${ }^{* * *},{ }^{* *}$ and $*$ denote a t-statistic at the one, five and ten percent significance levels, respectively. All equations are estimated from 21 annual observations (1972-1992) using Zellner's iterative Seemingly Unrelated Regressions (SUR) technique and an AR1 correction. Equations are estimated with a constant, time trend, and a control for annual output in the product's related 4-digit SIC industry, but their associated coefficients are not reported here. 
Figure 1: Japanese Automobile Production in the United States, Exports of Automobiles to the U.S. Market, and the Yen-Dollar Exchange Rate, 1972-92

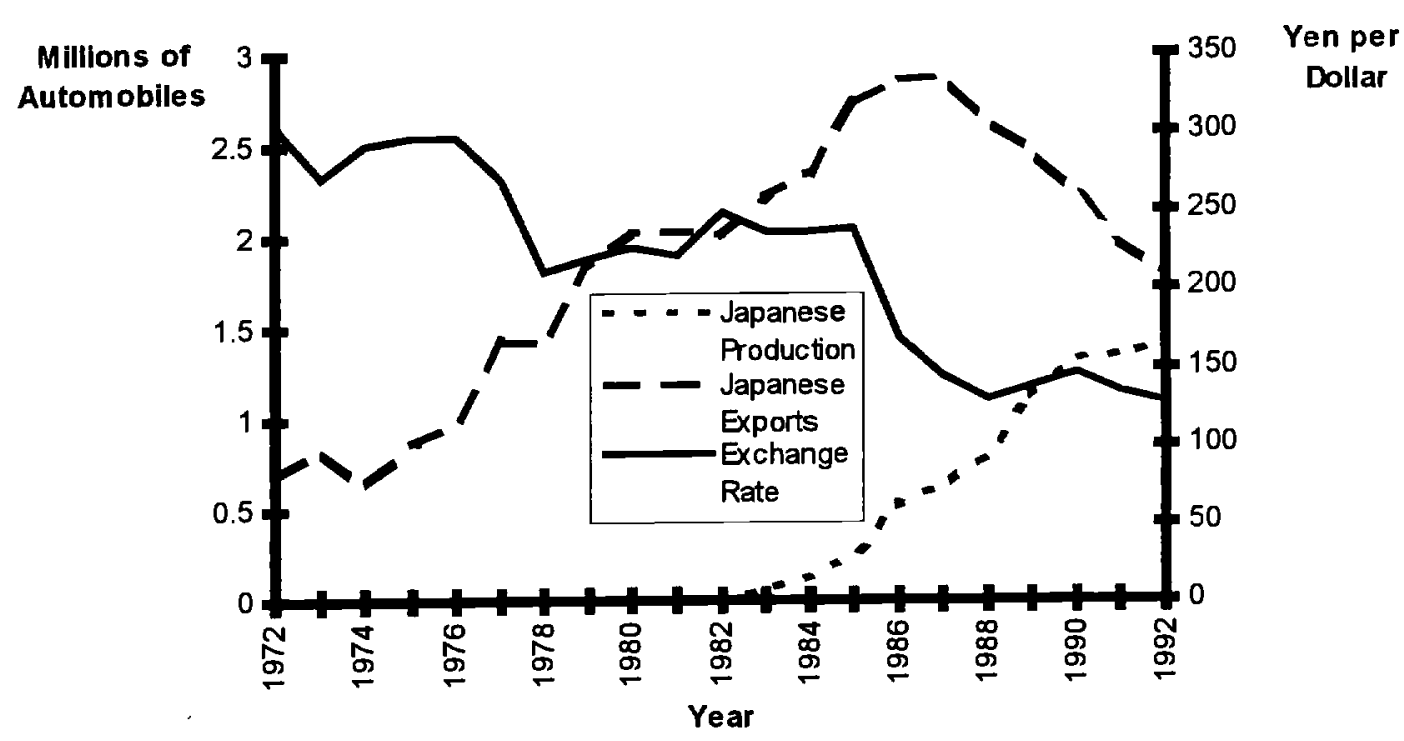

Figure 2: Japanese Auto Part Exports to the United States and Yen-Dollar Exchange Rate, 1972-92

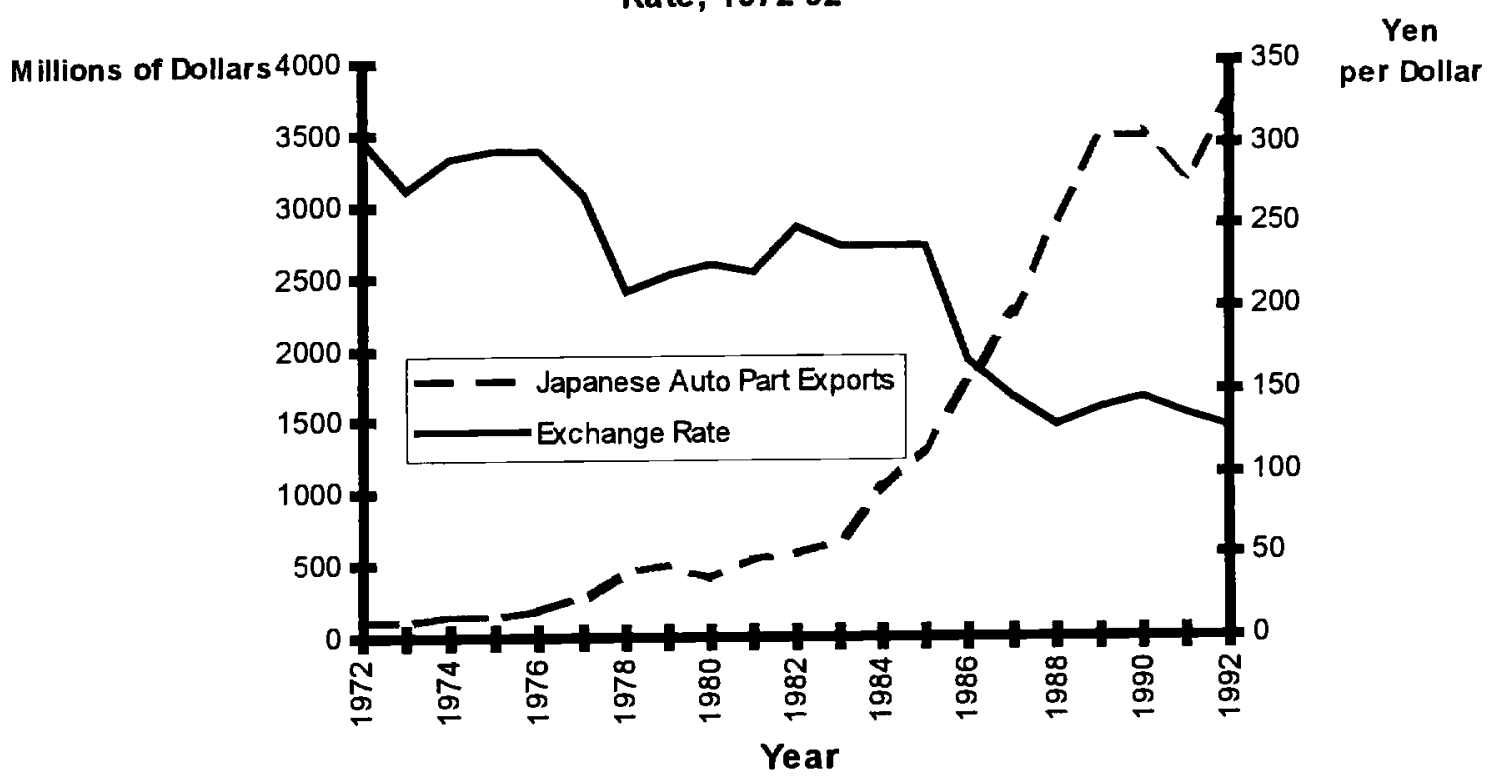


FIGURE 3A: Laminated Safety Glass: Japanese Exports to the United States and Production in the United States, 1978-1991

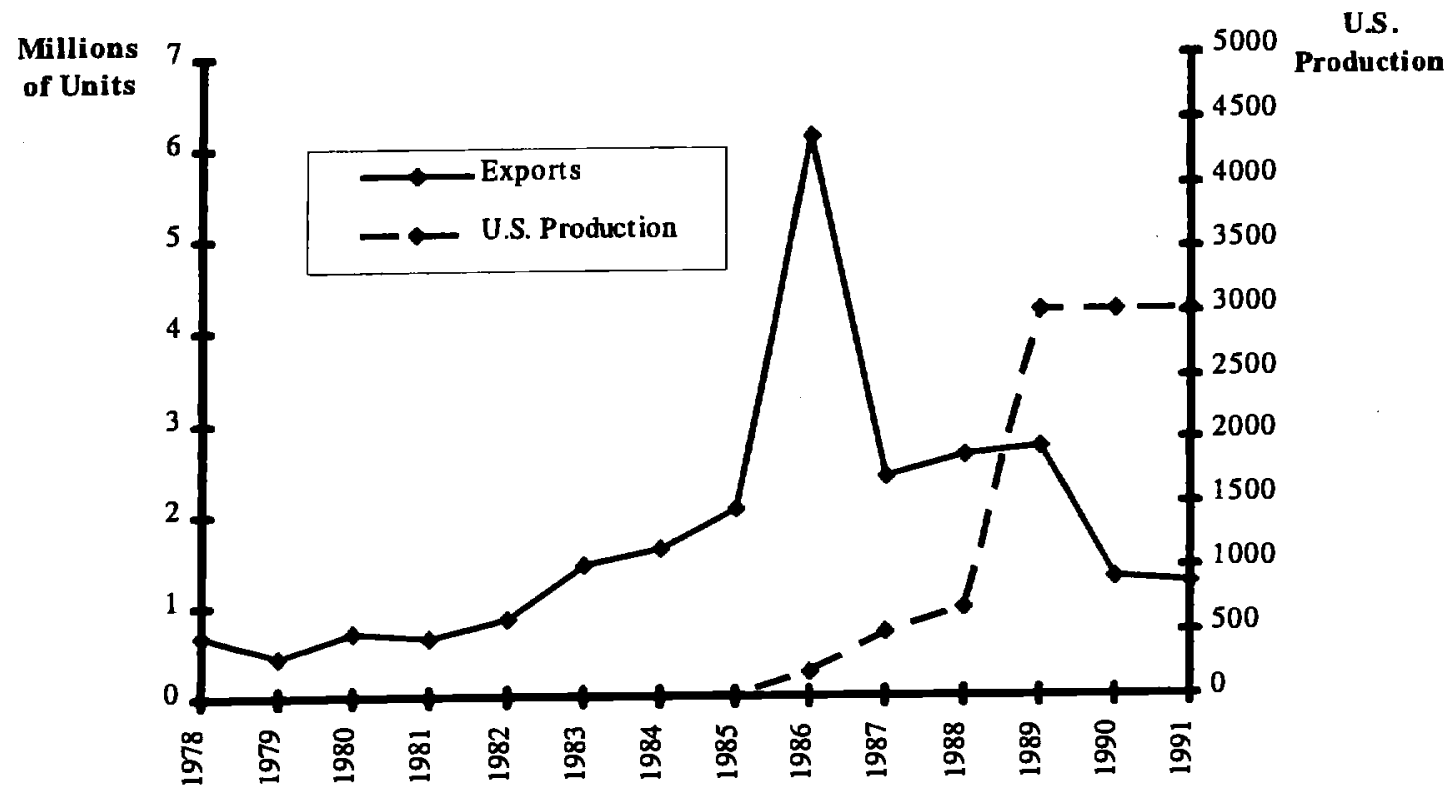

FIGURE 3B: Radio-cassette Players: Japanese Exports to the United States and Production in the United States, 1978-1991

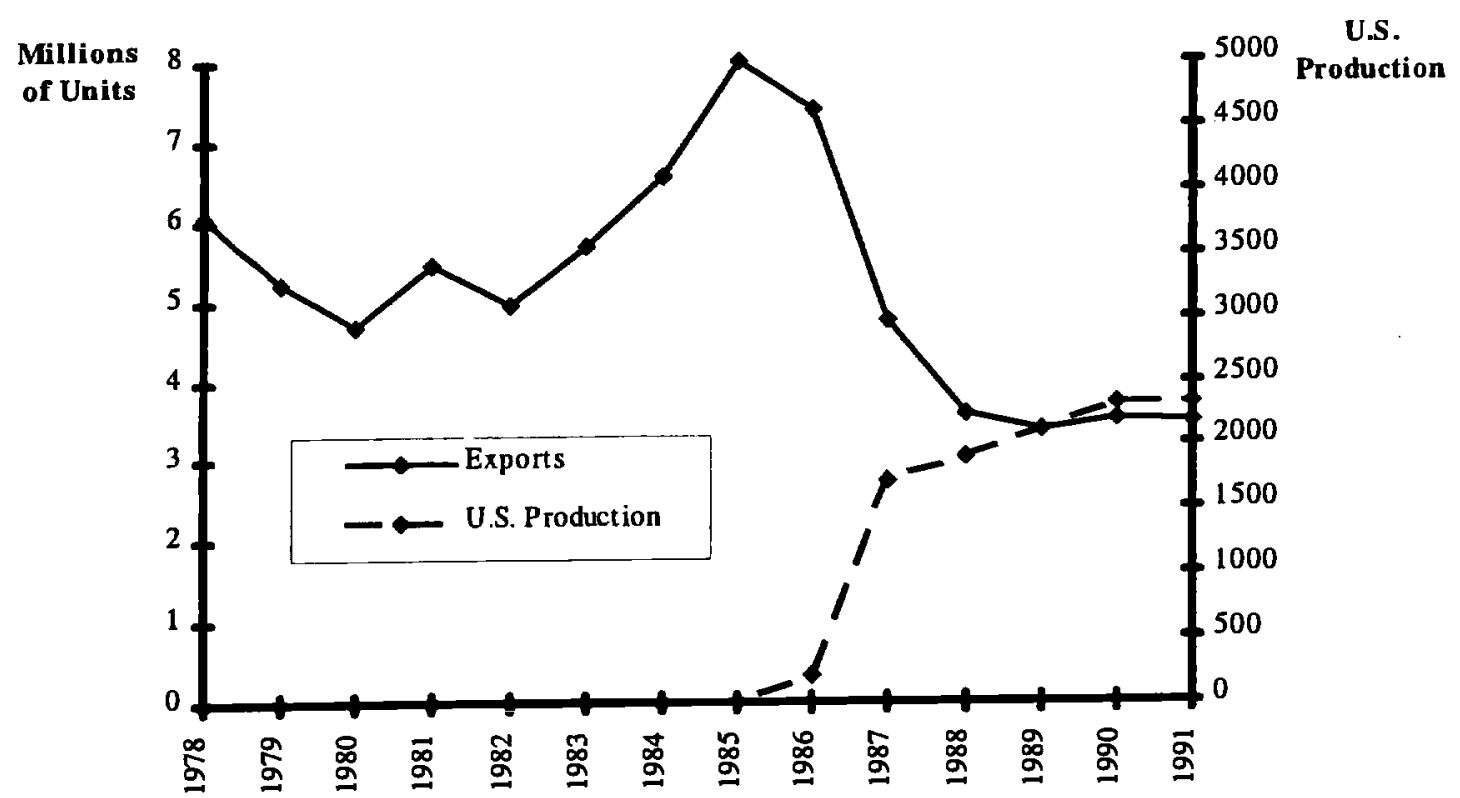


FIGURE 3C: Bumpers: Japanese Exports to the United States and Production in the United States, 1978-1991

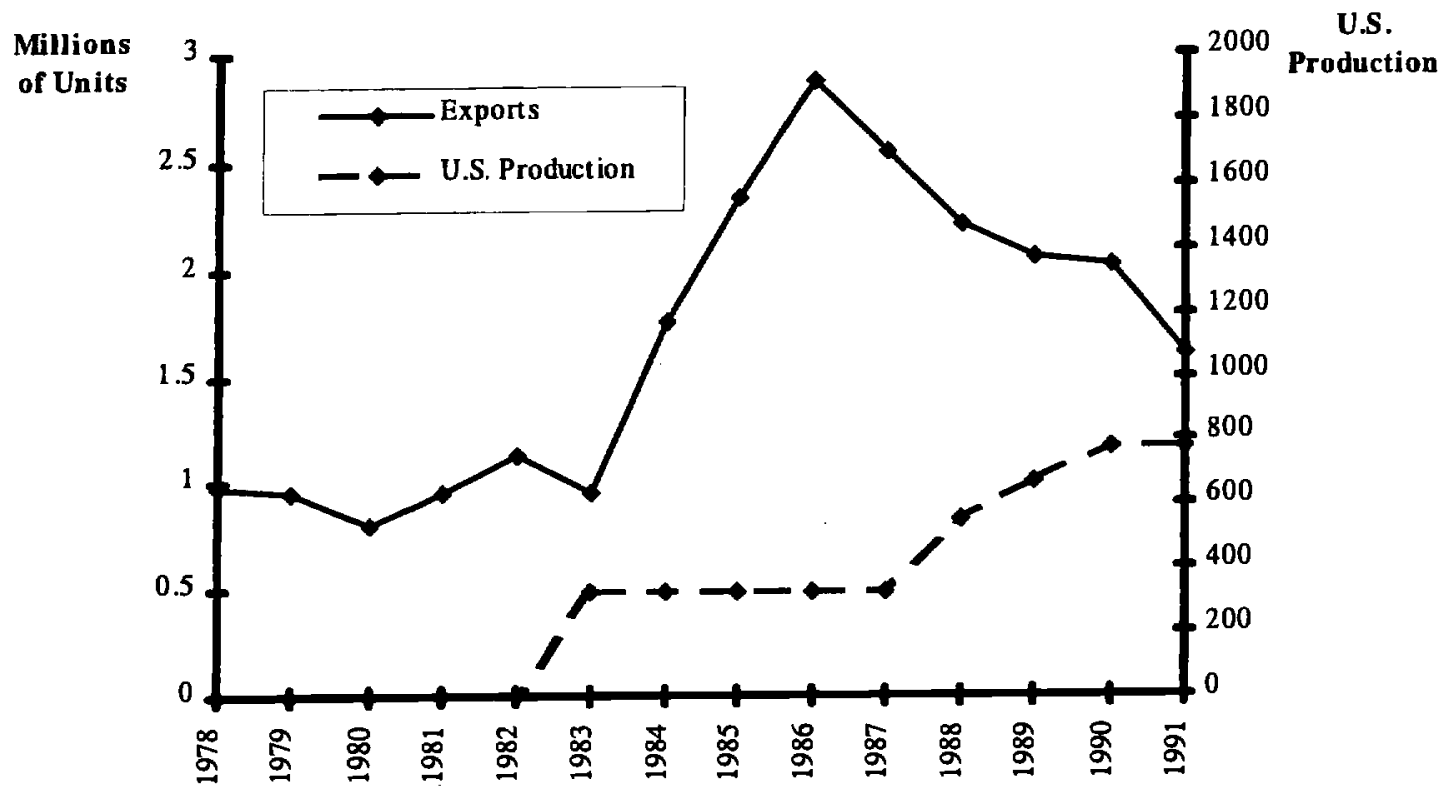

FIGURE 3D: Engine Starters: Japanese Exports to the United States and Production in the United States, 1978-1991

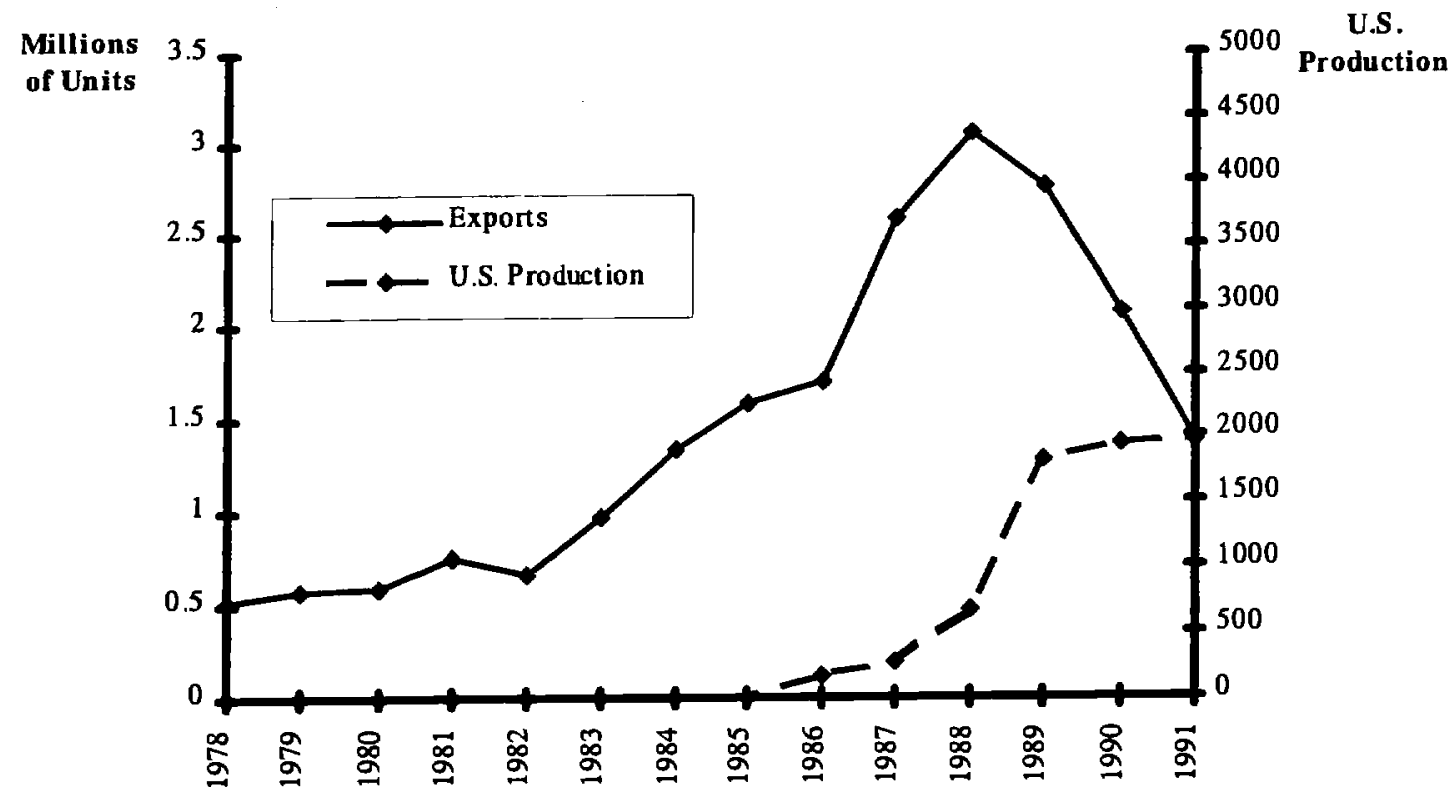


FIGURE 4A: Hand Vacuum Cleaners: Japanese Exports to the United States and Production in the United States, 1972-1994

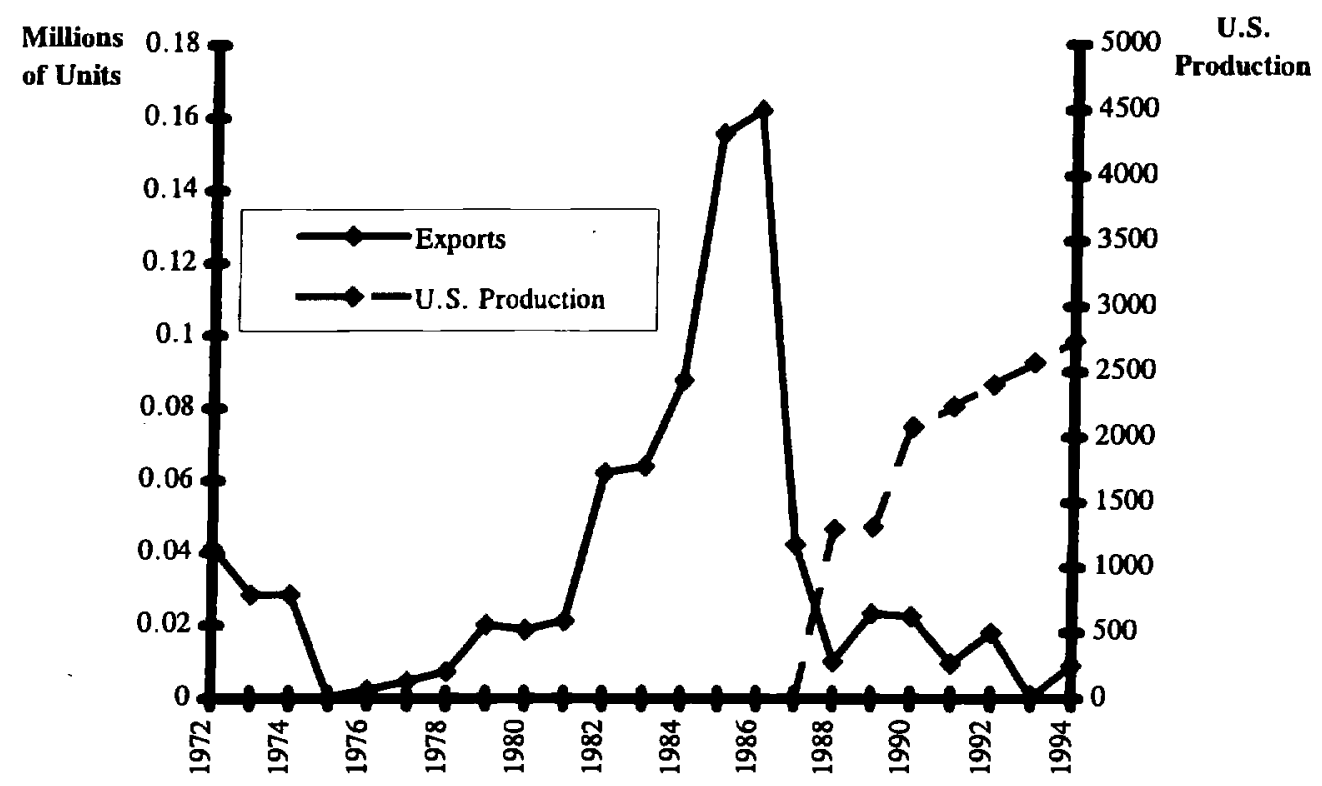

FIGURE 4B: Music Synthesizers: Japanese Exports to the United States and Production in the United States, 1979-1994

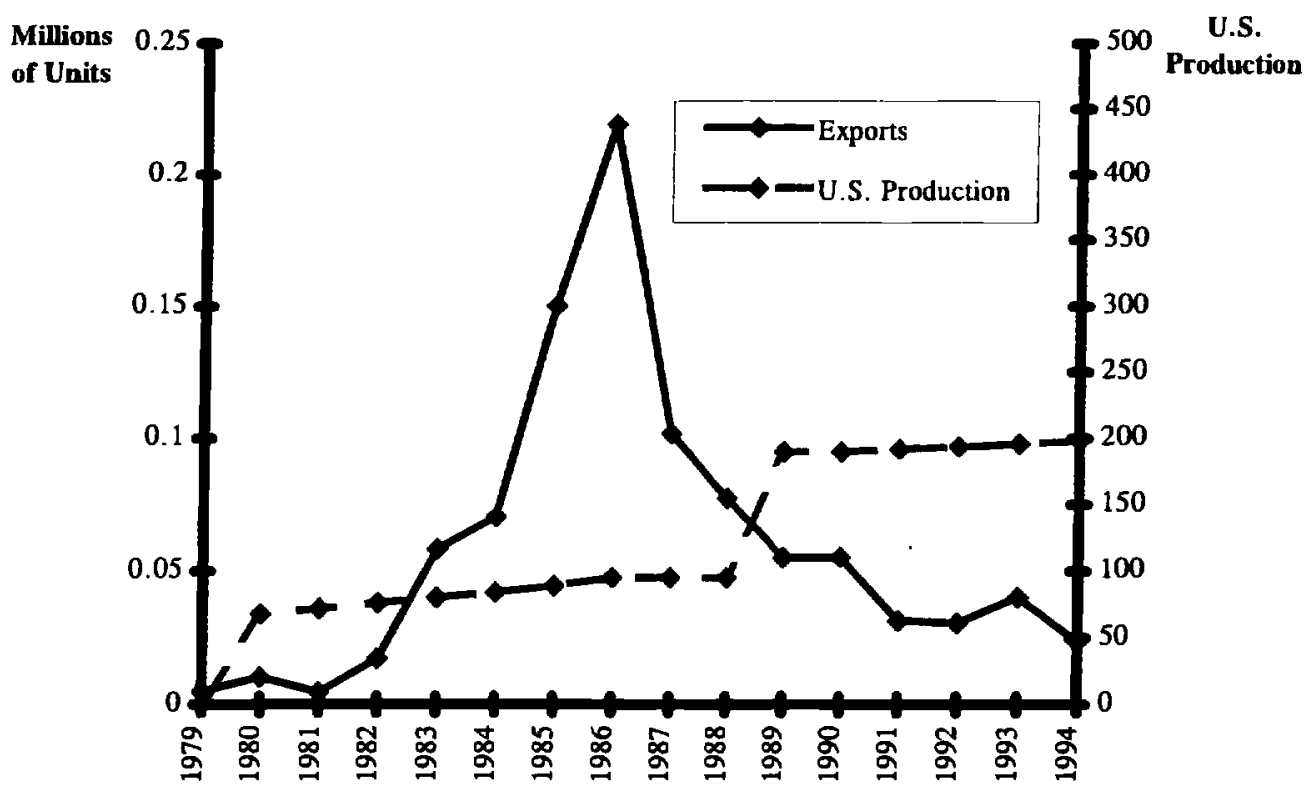


FIGURE 4C: Sake: Japanese Exports to the United States and Production in the United States, 1972-1994

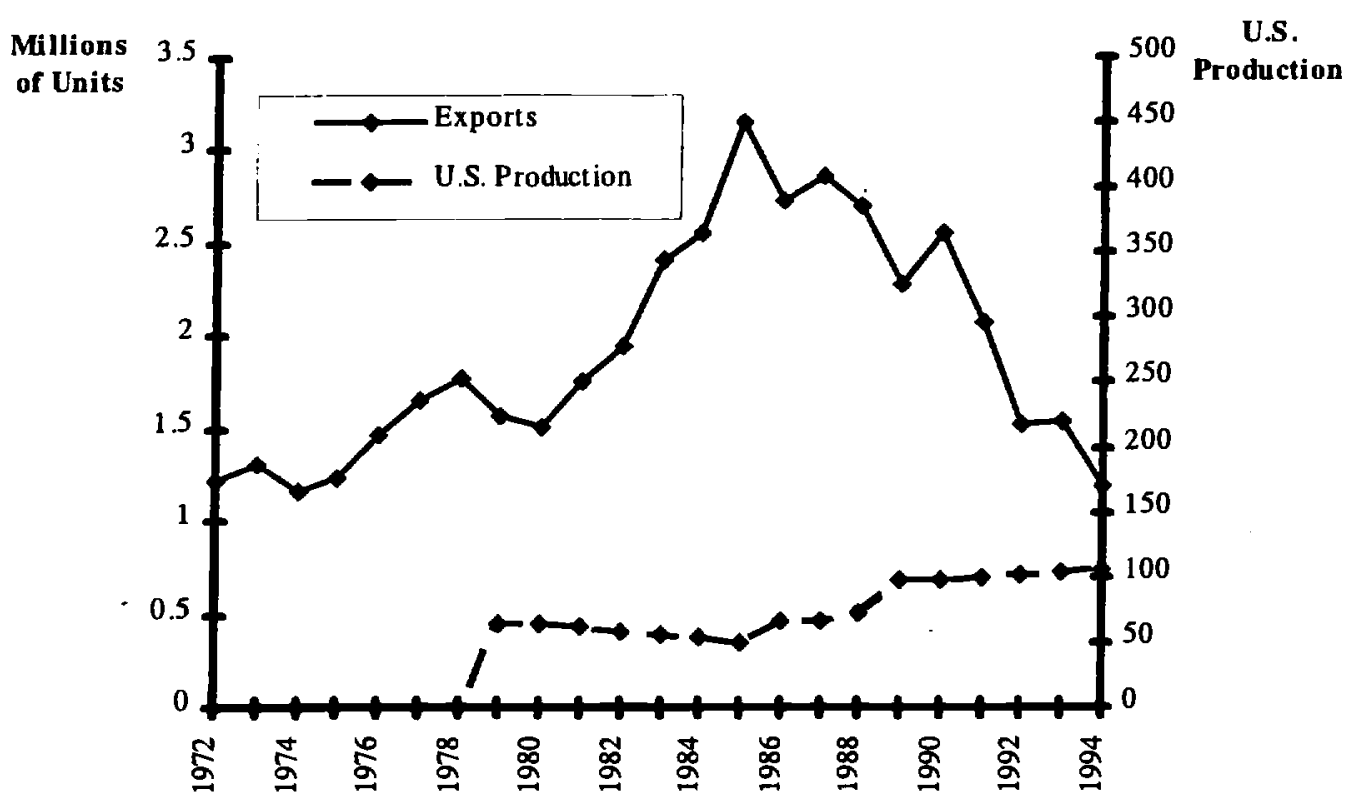

FIGURE 4D: Soy Sauce: Japanese Exports to the United States and Production in the United States, 1972-1994

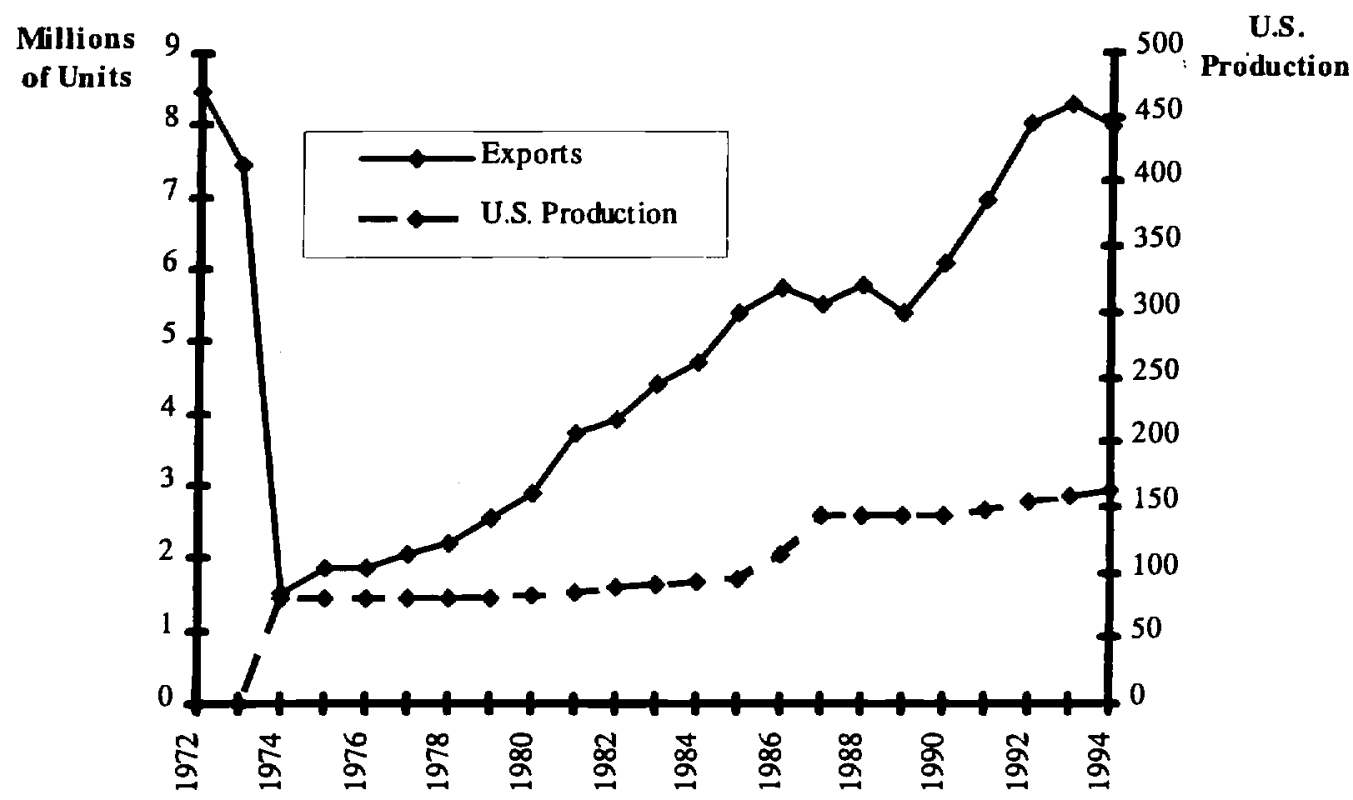




\section{Data Appendix}

\section{Automobile parts regressions:}

Import quantity and price data for the ten automobile part regressions come from the recently released National Bureau of Economic Research (NBER) Trade Database, Disk 1: U.S. Imports, 1972-1994, constructed by Robert Feenstra. As mentioned in the text, details on this database are found in Feenstra (1996). The ten products were chosen because there was a clean one-to-one mapping between Tariff Schedules of the United States Annotated (TSUSA) codes and Harmonized Tariff System (HTS) codes and there was significant Japanese production of these products in the United States beginning in the 1980s.

The data collected begin in year 1978, since the classification codes do not clearly separate out many of the products of interest in earlier years. The following table gives the precise TSUSA and HTS mapping.

\begin{tabular}{ll} 
Product & TSUSA/HTS Product \\
\hline Toughened glass for autos & \\
$1978-1988$ & TSUSA: 5443100 \\
1989 & HTS: 7007110000 \\
$1990-1991$ & HTS: 7007110010
\end{tabular}

Laminated safety glass for autos 1978-1988 1989-1991

Automotive mirrors

1978-1988

1989-1991

Radio-cassette players for autos

1978-1982

1983-1988

1989-1991

Radio receivers for autos

1978-1982

1983-1988

1989-1991

Engine starters for autos

1978-1988

1989-1991

Engine coils for autos

1978-1988

1989-1991

Door locks for autos

1978-1988

1989-1991

TSUSA: 5444120

TSUSA: 6836040

HTS: 8511400000

TSUSA: 6836070

HTS: 8511300080
HTS: 7007211010, 7007215000

TSUSA: 5445100

HTS: 7009910000, 700911000
Measurement Unit

Square Feet

Square Meters

Square Meters

Square Feet

Square Meters

Number

Number

Number

Number

Number

HTS: 8527211010,8527211020

TSUSA: $6852110,6852115,6852125,6852150$

Number

Number

Number

HTS: 8527294020, 8527298040, 8527298060

Number

Number

Number

Number

Number

Number 
Bumpers for autos

1978-1979

1978-1988

1989-1991

Seats and parts for autos

1978-1988

1989-1990

1991
TSUSA: 6922720

TSUSA: 6923220

HTS: 8708100050

Not Applicable

Not Applicable

Not Applicable

Not Applicable

TSUSA: 7270600

HTS: 9401200000,9401901000

HTS : $9401200000,9401200090,9401901000$
Not Applicable

Not Applicable

For all these products, except bumpers and parts and seats and parts, U.S. Customs records both customs values and quantities. Thus, I calculate a "price", or unit value, by dividing value by quantity. For the other two products, I have used an average of the other imported automobile part prices to proxy for their price and divide their customs values to get some sort of quantity measure. Quantity data are scaled in millions.

Production of U.S. and Japanese autos in the United States are specified as millions of yearly automobiles produced and taken from Ward's Auto World.

Prices of U.S. automobile parts are representive price indexes of U.S. automobile parts from U.S. Bureau of Labor Statistics (BLS) wholesale price indexes. In most cases it was not possible to find indexes for the exact comparable automobile part. For example, for toughened and safety glass for autos I use the BLS price index for flat glass as the comparable U.S. automobile part price. I used the 6-month commercial paper interest rate as the price of capital reported in table B-72 of the Economic Report of the President, February 1995.

Finally, production of Japanese automobile parts in the U.S. is proxied by the number of employees (in hundreds) involved in U.S. production of these products for Japanese-owned firms. I have firm-level data of entry by Japanese automobile part firms (and a very specific listing of the product(s) they produce) into the United States and their 1986, 1988, and 1990 level of employees from the publications, Japan's Expanding Manufacturing Presence in the U.S., published by the Japan Economic Institute in Washington, DC, on a semi-annual basis. For years in between I interpolated assuming employee growth was constant over that period (i.e., I assumed it was the average of the two endpoint years). A detailed list of the firms and employee levels used for each product is available from the author upon request.

\section{Final consumer products regressions:}

Import quantity and price data come from the same source as for the automobile parts regressions. The following table gives the precise TSUSA and HTS mapping for these products. Output for each product is in millions. Prices for all products are unit values in U.S. dollars, except grand pianos, other pianos and music synthesizers, which are in thousands of U.S. dollars.

Product 
Other vacuum cleaners 1972-1985

1986

1987-1988

1989-1994

Microwave ovens

1972-1979

1980-1988

1989-1994

Grand pianos 1972-1988 1989-1994

Other pianos 1972-1988

1989-1994

Music synthesizers

1979-1982

1983-1986

1987-1988

1989-1994

Soy sauce

1972-1988

1989-1994

Sake

1972-1988

1989-1994

Ballpoint pens

1972-1988

1989-1994

Golf balls

1972-1994

1989-1994

Golf clubs, compete sets

1978-1988

1989-1994
TSUSA: 6833030

TSUSA: $6833030,6833033,6833036$

TSUSA: $6833033,6833037,6833038$

HTS: 8509100030, 8509100050, 8509100070, 8509100080

TSUSA: 6843010

TSUSA: 6842500

HTS: 8516500000

TSUSA: 7250320

HTS: 9201200000

Number

Number

TSUSA: 7250100,7250340

HTS: 9201100000,9201900000

Number

Number

TSUSA: 7254743

TSUSA: 7254742

TSUSA: 7254705, 7254710

HTS: 9207100005,9207100010

Number

Number

Number

Number

TSUSA: 1824500

HTS: 2103100000

Pounds

Kilograms

TSUSA: 1672500

Gallons

HTS: 2206004500

Liters

TSUSA: 7600520

Number

HTS: 9608100000

Number

TSUSA: 7347520,7347540

Dozens

HTS: 9506320000

Dozens

TSUSA: 7347720

Number

HTS: 9506310000

Number 
Production of Japanese firms in the U.S. is proxied by the number of employees (in hundreds) involved in U.S. production of these products for Japanese-owned firms, as with the automobile parts regressions. Unlike the automobile parts investment, some of these products were being produced in the United States before the mid-1980s, so I also used the 1980, 1984, 1986 and 1988 editions of Japan's Expanding Manufacturing Presence in the U.S. Estimates of employee levels in between data points (or before 1980) were interpolated (or extrapolated) assuming employee growth was constant over that period. Because there were less firms investing in the United States for these products, I was also able to determine or estimate employee levels for these firms through 1994. This was done either by contacting the firm or using various recent state-level directories of foreign firms. A detailed list of the firms and employee levels used for each product are available from the author upon request.

Income is measured as U.S. real GDP (in billions of dollars) as reported in the Economic Report of the President. Finally, an industry quantity control variable, used for the specifications in tables 4 and 5, was constructed in the following manner. The NBER Trade Database, Disk 1: U.S. Imports, 1972-1994, reports annual value of U.S. imports by 4-digit SIC and country for the years 1972-1992. For each product I took the value of its associated 4-digit SIC industry imports from Japan and subtracted the product's import value from that associated industry total. I then converted these adjusted industry U.S. import values into yen using the annual yen-dollar exchange rate reported in Economic Report of the President. Finally, I used annual export price indexes reported in the Japan Statistical Abstract, various issues, to convert these figures into real terms; i.e., into a "quantity" control. 